\title{
A tradição manuscrita da Crônica de D. Duardos I
}

Raúl Cesar Gouveia Fernandes*

RESUMO: O Palmeirim de Inglaterra, de Francisco de Morais, é o mais célebre livro de cavalarias português do Renascimento. Além das continuações impressas do Palmeirim, há outra que permanece inédita até hoje: trata-se da Crônica de D. Duardos, provavelmente redigida em fins do século XVI, que sobreviveu apenas em cópias manuscritas. O objetivo deste trabalho é examinar a tradição manuscrita da primeira parte da Crônica de D. Duardos, com vistas à preparação da publicação do texto.

PALAVRAS-CHAVE: Livros de cavalarias; tradição manuscrita; Renascimento português.

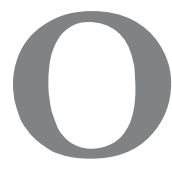

$\mathrm{s}$ livros de cavalarias constituem um dos gêneros literários mais populares do Renascimento. A partir da Península Ibérica, a prosa de ficção cavaleiresca difundiu-se por toda a Europa durante os séculos. XVI e XVII, desempenhando papel importante no processo de criação da narrativa moderna. Ainda assim, talvez porque as severas críticas de Cervantes tenham feito com que se concedesse pouca atenção àqueles livros que causaram a loucura do pobre $\mathrm{D}$. Quixote, o gênero cavaleiresco continua a ser menos valorizado que a ficção sentimental e a prosa picaresca do mesmo período. Não obstante o surgimento de numerosos trabalhos dedicados ao tema na última década, José Manuel Lucía Megías dizia ainda há poucos anos sobre os livros de cavalarias castelhanos: "todavía queda mucho por hacer; casi todo por analizar, comparar y conocer" (2002, p. 9). Em âmbito português, apesar das promissoras pesquisas de Isabel Adelaide Penha Dinis de Lima e Almeida e de Aurelio Vargas Díaz-Toledo, pode-se dizer o mesmo.

* Centro Universitário da FEI (Fundação Educacional Inaciana Pe. Sabóia de Medeiros) raulfernandes@terra.com.br. 
O presente trabalho é parte do projeto de edição da Crônica de D. Duardos, um dos tantos livros de cavalarias quinhentistas portugueses que permanecem esquecidos há séculos; pretendemos oferecer, assim, nossa contribuição ao conhecimento de um gênero que reputamos indispensável para a compreensão da literatura do Renascimento em Portugal. Trata-se da continuação manuscrita do célebre Palmeirim de Inglaterra e, como outros livros de cavalarias da época, a Crônica de D. Duardos é dividida em três partes. Segue abaixo a localização dos 15 testemunhos conhecidos do texto. ${ }^{1}$

\section{Crônica de D. Duardos I (sete cópias):}

- Biblioteca Nacional de Lisboa (BNL), Seção de Reservados: cód. 483, cód. 619; cód. 620; cód. 658; cód. 6828; cód. 12904.

- Arquivo da Torre do Tombo (T'T): Manuscritos da Livraria, cód. 1773 (1 $1^{\mathrm{a}}$ parte).

2. Crônica de D. Duardos II (cinco cópias):

- BNL, Seção de Reservados: cód. 659; cód. 6829.

- TT: Manuscritos da Livraria, cód. 410; cód. 1201.

- Biblioteca do Paço Ducal de Vila Viçosa: Seção de Reservados.

3. Crônica de D. Duardos III (três cópias):

- BNL, Seção de Reservados: cód. 6830.

- TT: Manuscritos da Livraria, cód. 1202 e cód. 1773 (2ªrte).

A descoberta desses códices levantou uma série de problemas. Além das questões sobre a autoria e a datação do texto, às quais os manuscritos não oferecem respostas, há outras dúvidas que até o momento não haviam sido respondidas adequadamente. A principal delas diz respeito à existência de continuações impressas do Palmeirim de Inglaterra. Como se sabe, o Palmeirim, redigido por Francisco de Morais e editado pela primeira vez em cerca de

Justificar aqui o motivo de não adotarmos os títulos propostos por Massaud Moisés (1957) às diversas partes do texto escaparia aos objetivos deste trabalho; sobre esta escolha, cf. Fernandes, 2006, p. 39-41. A Crônica de D. Duardos não é o único livro de cavalarias português inédito: há notícias de mais algumas obras manuscritas que ainda aguardam edição, como a Crônica do Imperador Beliandro, de D. Leonor Coutinho, o Leomundo de Grécia, de Tristão Gomes de Castro, e a anônima História do Príncipe Belidor e da Princesa Corsina. A Crônica do Imperador Maximiliano, livro anônimo também preservado apenas em cópia manuscrita, foi editada em 1983. Cf. Aurelio Vargas Díaz-Toledo, 2006, p. 239-240, em que há notícia de outros livros de cavalarias portugueses perdidos. 
1544, alcançou grande sucesso e deu origem a duas continuações impressas em Lisboa entre o final do século XVI e o início do seguinte: em 1587 Diogo Fernandes trouxe a lume a Terceira [e Quarta] parte da Chronica de Palmeirim de Inglaterra na qual se tratam as grandes cauallarias de seu filho o Principe Dom Duardos (Lisboa: Marcos Borges), obra reeditada em 1604 (Lisboa: Jorge Rodriguez); em 1602 foi a vez de Baltasar Gonçalves Lobato apresentar a Quinta e sexta parte de Palmeirim de Inglaterra. Chronica do famoso Principe Dom Clarisol de Bretanha (Lisboa: Jorge Rodriguez). ${ }^{2}$

Os raríssimos estudiosos que se defrontaram com o problema manifestaram sua perplexidade diante da existência de dois diferentes grupos de continuações do Palmeirim: o das seqüências impressas e o das manuscritas. Fidelino de Figueiredo, o primeiro a tratar do assunto, já intuía que os manuscritos em questão fossem testemunhos de uma derivação autônoma do "ciclo dos Palmeirins", diversa das continuações impressas já conhecidas do Palmeirim de Inglaterra (1930, v. 3, p. 29-34). Massaud Moisés, a quem devemos a identificação das três partes em que se divide a Crônica de D. Duardos, considerou duas hipóteses, não excludentes entre si: que os textos manuscritos fossem do mesmo autor do Palmeirim, Francisco de Morais, e que poderiam ser cópias de versões anteriores à publicação da Terceira e Quarta Partes, de Diogo Fernandes, posteriormente refundidas por ele (1957, p. 49-50). João Palma-Ferreira (1983, em esp. as p. 58-64), por sua vez, supôs que as continuações manuscritas fossem reelaborações posteriores aos livros impressos, atribuindo sua autoria a D. Gonçalo Coutinho, que figura como autor de uma misteriosa História de Palmeirim de Inglaterra e de D. Duardos na Bibliotheca Lusitana de Barbosa Machado.

No decurso de nossas pesquisas, pudemos retificar algumas das hipóteses propostas e sugerir outras. Ao menos na primeira parte da Crônica de D. Duardos, não há indícios que corroborem as teses de Moisés e Palma-Ferreira, segundo as quais a continuação manuscrita seria rascunho preliminar ou refundição posterior da Terceira e Quarta Partes do Palmeirim, de Diogo Fernandes. A comparação entre as obras sugere, ao contrário, que o D. Duardos seja um

2 É oportuno observar que o Palmeirim já continha duas partes; daí que as continuações principiem pela terceira. Todas essas obras são de difícil acesso ao leitor de hoje: a última edição do Palmeirim (1946) encontra-se há muito esgotada e as continuações de Fernandes e Lobato nunca voltaram a ser editadas. As demais partes do "ciclo dos Palmeirins", obras castelhanas que antecedem o livro de Francisco de Morais, foram recentemente publicadas na coleção "Libros de Rocinante", do Centro de Estudios Cervantinos da Universidade de Alcalá de Henares, em edições preparadas por M. Carmen Marín Pina: Palmerín de Olivia (de 1511), Primaleón (1512) e Platir (1533). A mesma coleção lançou em 2006 a tradução castelhana da primeira parte do Palmerín de Ingalaterra (impressa em Toledo no ano de 1547), em edição preparada por Aurelio Vargas Díaz-Toledo. 
livro autônomo, escrito sem que seu autor tivesse conhecimento das continuações impressas. Por isso acreditamos que o autor da Crônica de D. Duardos (provavelmente D. Gonçalo Coutinho) deva ter redigido sua obra antes de 1587, ano da edição da Terceira e Quarta Partes. ${ }^{3}$

Os 7 manuscritos que conservam a primeira parte da Crônica de D. Duardos, os únicos de que nos ocuparemos aqui, são cópias do século XVII (exceto um, que data do século XVIII) e de modo geral estão bem conservados. As siglas com que os designaremos doravante são as seguintes:

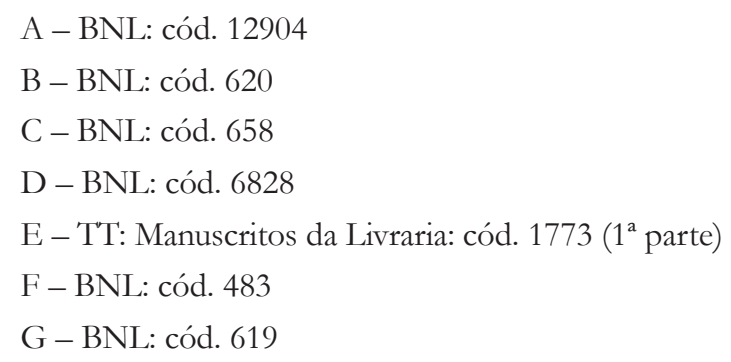

Em síntese, a história da descoberta e identificação dos testemunhos da Crônica de D. Duardos I teve início nos anos 1920, quando Fidelino de Figueiredo informou a localização de cinco códices (os manuscritos B, C, D, F e G), mas, enganado pela discrepância dos títulos, não notou que se tratavam de cópias de um mesmo texto. ${ }^{4}$ Em 1957, Massaud Moisés corrige o equívoco e acrescenta à lista o códice E, o único que não se encontra na Biblioteca Nacional de Lisboa. A organização dos textos proposta na "achega bibliográfica" de Moisés (que apresenta ainda a descoberta de outros livros de cavalarias manuscritos dispersos por várias bibliotecas portuguesas) foi reproduzida em todos os estudos posteriores que mencionam os referidos manuscritos, como os de Ettore Finazzi-

É nossa intenção publicar em breve um estudo justificando mais detalhadamente nossas conclusões.

4 Figueiredo, 1930, v. 3, p. 29-34. Além desses códices, o autor dá notícia de diversos livros de cavalarias inéditos. Cumpre observar, entretanto, que algumas informações apresentadas por Figueiredo são inexatas. A Selva de Cavallarias Famožas não se vincula ao ciclo dos Palmeirins, como o autor dá a entender. Além disso, um manuscrito referido parece estar com a numeração errada: trata-se do n 6483 (B-6-55) que, de acordo com a descrição de Figueiredo, identifica-se com o $n^{\circ} 483$ (B-6-35), aqui referido como F. Não descobrimos se houve mudança na numeração do manuscrito (o que é pouco provável) ou se a falha se deve a erro tipográfico (a $1^{a}$ edição do livro, que também consultamos, traz a mesma informação). Antes de Figueiredo, Teófilo Braga e William Purser já haviam dado notícias vagas sobre continuações manuscritas do Palmeirim (cf. Purser, 1904, p. 393-394). 
Agrò (1978, p. 65-71) e Luciana Stegagno Picchio (1979, p. 205-206), entre outros. Em 1983, João Palma-Ferreira apresenta descrição mais detalhada dos cinco manuscritos já localizados por Figueiredo na BNL, afirmando terem sido infrutíferas suas tentativas de localização de novas cópias. ${ }^{5}$ Foi apenas muito recentemente que surgiu a primeira notícia sobre a existência do cód. BNL 12904 (A), descoberto por Aurelio Vargas Díaz-Toledo (2004, p. 4).

\section{Descrição sumária dos códices}

\section{Códice A (BNL 12904)}

O códice apresenta texto com 80 capítulos e ostenta no fólio inicial o seguinte título: "Chronica de Primaleão Emperador de Grecia Primeira Parte Em que se da conta das façanhas, que obrou o Princepe D. Duardos, e os mais Princepes que com elle se criarão, na Ilha Perigoza do Sabio Daliarte Composta Por Guilherme Frusto, Author Hibernio, e copiada, por Simisberto Pachorro, em quanto esteve occupado, ou encantado no Cume da Penha Riguroza, da Serra da Lua, pello odio do Sabio Bragamante". O códice é composto por 262 fólios numerados de 294 x $206 \mathrm{~mm}$, mais a folha de título e uma folha de guarda ao final. Entre os fols. 259r e 262v há um "index" dos capítulos da obra, numerados por outra mão. A letra do único copista aparenta ser do século XVII e é bastante clara. ${ }^{6} \mathrm{O}$ manuscrito, que carece de toda decoração, foi adquirido pela BNL em 1987, em leilão promovido pelo livreiro José Manuel Rodrigues. O catálogo do leilão, por nós consultado, não traz qualquer indicação sobre a origem do códice, embora se saiba que ele pertenceu à família dos Condes do Bomfim, como testemunha o ex-libris colado à contra-capa da frente. ${ }^{7}$

\section{Códice B (BNL 620)}

O códice apresenta texto composto por 80 capítulos, cujo título é "Chronica de Primaleão Emperador de Grecia Primeira parte Em que se da

5 Palma-Ferreira, 1983, p. 9-33. Também aqui há erro de numeração em um manuscrito apresentado: o que, na p. 21, aparece com o número 569, na verdade é o 659.

6 Este é o único códice para o qual não dispúnhamos de quaisquer estimativas de datação, por ter sido descoberto há poucos anos. Embora não tenhamos prática em exames paleográficos, a comparação com outros textos da época parece indicar a segunda metade do século XVII como data provável da cópia.

7 O catálogo do leilão no qual o códice foi adquirido pela Biblioteca informa apenas que boa parte dos livros leiloados pertencia a Arnaldo H. Oliveira, de quem não conseguimos outras notícias. 
conta das façanhas, que obrou o Principe D. Duardos, e os mais Principes que com elle se criarão na Ilha Perigoza do Sabio Daliarte. Composta Por Guilherme Frusto Author Hibernio, e copiada, por Simisberto Pachorro, emquanto esteve occupado, ou encantado no cume da Penha Riguroza, da Serra da Lua, pello odio do Sabio Bragamante". O códice é composto por 179 fólios de texto, numerados pelo copista (com alguns erros), mais uma folha de guarda ao início, a folha de título e, depois do texto, o índice (que ocupa 3 fols.) e as duas folhas de guarda ao final. A dimensão dos fólios é de 320 x $214 \mathrm{~mm}$. O códice foi escrito por uma única mão, e a letra, excepcionalmente clara, aparenta remontar ao século XVII (Figueiredo, 1930, v. 3, p. 32-3; Palma-Ferreira, 1983, p. 33). Não há decoração ou qualquer elemento que permita descobrir quem teriam sido os antigos proprietários do códice ou quando ele foi adquirido pela $\mathrm{BNL}$.

\section{Códice C (BNL 658)}

O códice traz cópia da "Chronica do Emperador Primalião, e outros Principes”, em 80 capítulos. Os fols. medem 207 x 191 mm e o códice é composto por 202 fólios de texto, mais a folha de título do início e uma de guarda ao final. Trata-se da única cópia da Crônica de D. Duardos I feita a duas mãos. O primeiro punho segue até a metade do capítulo 64 (f. 169r), e a porção copiada pelo segundo punho inicia com a repetição de um pequeno trecho já transcrito pelo primeiro amanuense. Segundo Figueiredo (1930, v. 3 , p. 33), a letra dos dois copistas aparenta ser da segunda metade do século XVII. Os fólios foram numerados duas vezes, de acordo com critérios distintos: a numeração presumivelmente mais antiga aparenta ter sido feita pelo primeiro copista e segue apenas até o f. 169, não isenta de erros; há outra numeração, feita a lápis, que abrange a totalidade do códice. Durante a encadernação, alguns fólios saíram da ordem primitiva: identificamos ao menos um trecho (entre os fols. 159 e 161) em que eles estão na posição errada. Em outro trecho (fols. 115 a 120), o papel utilizado é de qualidade, textura e cor completamente diferentes dos demais. Um fólio (78r) foi deixado em branco, sem que isso acarretasse perda de parte do texto: o f. $77 \mathrm{v}$ é, inclusive, o único que apresenta reclame, provavelmente porque o copista quis assegurar aos leitores a integridade do texto. O códice carece de toda decoração e, de acordo com selo encontrado na contracapa da frente, pertenceu a António Lourenço Caminha. ${ }^{8}$

Segundo Inocêncio Francisco da Silva, Caminha foi nomeado por D. João VI ao cargo de Oficial da Biblioteca Pública de Lisboa provavelmente como agradecimento pela doação 


\section{Códice D (BNL 6828)}

O códice traz cópia da "Chronica do Invicto D. Duardos de Bretanha Princepe de Ingalaterra filho de Palmeiry, e da Princeza Polinarda, daqual seconta seus estremados feitos em Armas, e purisimos Amores, Com outros de outros Cavalleiros que en seu tempo Concorrerão. ComPosta por Henrrique Frusto Chronista ingres, etresladada em Portugues por Gomes Ennes de Zurara que fes a Chronica del Rey Dom Afonço Henrriques dePortugal achada denovo entre seus Papeis", texto com 80 capítulos. A dimensão dos fólios é de 292 x $200 \mathrm{~mm}$ e o códice consta de 175 fols. numerados, sem contar as folhas de guarda (duas no início e uma ao final) e título. A partir do f. 168r, começa o "index dos Capitulos que comtem este Livro", que vai até o f. 170v, ao qual se seguem outros 5 fols. numerados, mas em branco. No início do códice foi colada uma carta de duas páginas, datada de 14 de fevereiro de 1875. Nela, o bibliógrafo Inocêncio Francisco da Silva, dirigindo-se ao antigo proprietário do volume, o Visconde de Fonte Arcada, manifesta surpresa com a "descoberta" de novo texto de Zurara. O códice foi copiado por um único amanuense e não apresenta decoração. De acordo com Figueiredo, a cópia deve remontar ao século XVII, embora ele mesmo diga haver quem discorde da opinião, afirmando tratar-se de caligrafia do século XVIII (1930, v. 3, p. 32). A julgar pela carta de Inocêncio, o códice deve ter pertencido a António Francisco Jacques de Magalhães, o $5^{\circ}$ Visconde de Fonte Arcada (1793-1880).

\section{Códice E (TT, Manuscritos da Livraria, 1773-1 ${ }^{a}$ parte)}

Trata-se da "Primeira parte da vida de Primalião Emperador de Constantinopla e de outros Princepes daquele tempo", composta por 80 capítulos, encadernada juntamente com cópia da Crônica de D. Duardos III ("Terceira Parte da chronica do Principe Dom Duardos"), ambas copiadas pelo mesmo amanuense. O códice é composto por 317 fols. de 283 x $189 \mathrm{~mm}$, contando com uma folha de guarda ao início, a folha de título no início da "Terceira Parte" e 17 fols. em branco ao final, talvez reservados para o índice dos capítulos. O primeiro livro ocupa os fols. 1r a 154v; o texto da "Terceira Parte" começa no f. 156r e vai até o f. 299v. Há dois fols. rasgados (169 e o 226). A pequena letra do amanuense e o estado geral do códice, que se encontra muito escurecido, tornam a leitura do texto extremamente trabalhosa. $\mathrm{O}$

"de uma porção de livros velhos, e alguns manuscriptos, que elle qualificava de raríssimos". Caminha, que teria morrido em 1831 "em edade muito provecta", teria sido ainda autor de obras poéticas, opúsculos históricos, traduções e edições de textos antigos (SILVA, 1973, v. 1, p. 188-190). 
corte do papel para encadernação afetou a numeração em diversos fols. $\mathrm{O}$ códice carece de decoração e ao final da Crônica de D. Duardos I (f. 154v) o copista anotou: "Este livro he daSenhora D. Britis de Lima. Foi acabado em doze dejulho de 1668". ${ }^{9}$ Dentre as várias personagens com esse nome encontradas na História Genealógica da Casa Real Portuguesa, de D. António Caetano de Souza, há uma que foi sobrinha de D. Leonor Coutinho, ela também autora de um livro de cavalarias (a Crônica do Imperador Beliandro). Como a tia, Britis de Lima também parece ter tido interesse por livros, visto que em 1648 mandou publicar obra genealógica redigida pelo pai, Álvaro Pires da Távora, senhor do Morgado da Caparica. É provável que esse códice seja cópia do mencionado em carta de D. Vasco Luiz da Gama, filho de D. Leonor, na qual ele informa ter recebido cópias de um livro de cavalarias de D. Gonçalo Coutinho. ${ }^{10}$

\section{Códice F (BNL 483)}

"Primeira Parte Da vida de Premelião Emperador de Constantinopla, e de outros Principes da quelle tempo", texto composto por 80 capítulos. O códice consta de 211 fols. numerados (com pequenos erros), mais as folhas de guarda não numeradas: uma no início e duas ao final. A dimensão dos fólios é de 312 x $221 \mathrm{~mm}$. Anotações no canto direito inferior de alguns fólios permitem supor que ele fosse originalmente composto por cadernos de 4 fols. cada. Ao final do texto, no f. 211r, lê-se a data "30 de junho de 1449", certamente falsa. Trata-se de cópia tardia, feita por um único punho, com letra do século XVIII (Figueiredo, 1930, v. 3, p. 33; Palma-Ferreira, 1983, p. 33). O códice não apresenta decoração e pertenceu a António Ribeiro dos Santos, que foi o primeiro bibliotecário mor da então Biblioteca Pública de Lisboa, a partir de 1796, período no qual deve ter feito a doação do manuscrito ao acervo da instituição. ${ }^{11}$

9 Não há motivos para duvidar da informação. Por outro lado, não conhecemos estimativas de datação da caligrafia deste códice: sendo o único testemunho da primeira parte da Crônica de D. Duardos que não pertence à Biblioteca Nacional, não foi objeto de comentários de Figueiredo e Palma-Ferreira.

10 Cf. a História Genealógica, de Souza (1953, tomo XII, parte I, p. 51). A carta de D. Vasco Luiz da Gama (de 1649) foi publicada por Ramos Coelho (1903, p. 17-18). Convém observar que, apesar da coincidência dos sobrenomes, D. Gonçalo Coutinho e D. Leonor Coutinho não são parentes.

11 Inocêncio Francisco da Silva informa que os manuscritos doados por António Ribeiro dos Santos à Biblioteca "excediam entre livros e folhetos o número de oitocentos" (1973, v. 1, p. 249). 


\section{Códice G (BNL 619)}

A cópia é intitulada "Chronica de D. Duardos Primeira parte" e, diferentemente de todos os outros testemunhos do texto, é composta por apenas 74 capítulos. $^{12}$ A dimensão dos fólios é de 290 x $197 \mathrm{~mm}$. O códice consta de 201 fols. de texto, mais uma folha de guarda inicial e duas finais, não numeradas. No canto superior direito dos fólios retos há sinais de três numerações realizadas em épocas diferentes e seguindo critérios distintos. Dois fols. do códice possuem remendos. No f. 46, o pedaço danificado fica nas margens do texto e não prejudica a leitura; no f. 55 , ao contrário, pequenas partes do texto foram comprometidas. A letra do único copista "é indubitavelmente do século. XVII" (Palma-Ferreira, 1983, p. 32). A cópia não apresenta qualquer tipo de decoração e foi realizada em duas colunas. Há alguns capítulos sem título, embora o copista tenha deixado espaço reservado para ele: são os de número $18,20,21,23,25$ e 26 . O copista também havia deixado o capítulo 17 sem título, mas ele foi posteriormente acrescentado por outro punho: nota-se que a letra e a tinta utilizadas são diferentes. $O$ fato deve estar relacionado à peculiar distribuição da matéria narrativa que caracteriza esta cópia, como veremos adiante. Não há informações relativas aos antigos proprietários do códice ou de quando ele foi adquirido pela BNL.

\section{Colação dos códices}

Posto que se trata de texto muito extenso, restringimos a colação de todos os testemunhos da Crônica de D. Duardos I a certos trechos: além dos capítulos inicial e final, foram cotejados os capítulos 11-12 e 59-62 (por constituírem "lugares críticos", uma vez que, como veremos, correspondem a trechos em que a lição de $G$ poderia apresentar mais divergências) e ainda o capítulo 64 (onde há mudança de copista em C), perfazendo um total de 9 capítulos, ou mais de $10 \%$ do total da obra. ${ }^{13}$

12 Embora a numeração prossiga até o número 76, o códice possui apenas 74 capítulos, visto que faltam os de número 56 e 57.

13 Seguimos o método recomendado para textos como a Crônica de D. Duardos: "No caso de termos uma obra, ao mesmo tempo, muito extensa, e transmitida por muitos mss., é geralmente admitido que a 'collatio' não cubra a totalidade do texto, limitando-se a um cóngruo número de trechos, escolhidos seja de forma mecânica (aleatória), seja com base na sua notória dificuldade" (Spaggiari e Perugi, 2004, p. 33). Acerca da definição dos "lugares críticos", adotamos a sugestão de Spina: "Obras de certa extensão exigem um confronto mais demorado [...]. Daí o 
Dada a quantidade de variantes existentes entre os diferentes testemunhos, a colação permitiu colher material abundante. Com efeito, os copistas dos manuscritos analisados demonstram relativa liberdade para introduzir alterações no texto, além do fato de, em certas passagens, darem mostras de não compreender perfeitamente aquilo que transcreviam. Ainda que grande parte das discrepâncias sejam atribuíveis a meros lapsos mecânicos ou a preferências dos amanuenses (como é o caso de variantes ortográficas, omissões ou interpolações de artigos e pronomes, presença ou ausência de sinais de pontuação etc.), outras variantes há que permitiram formular hipóteses acerca da tradição manuscrita do texto. Na exposição que se segue restringiremos os exemplos a alguns casos significativos, sem pretensão de apresentar a lista exaustiva das variantes.

Embora preliminar (pois as conclusões da colação não apontam para um stemma codicum isento de dúvidas e lacunas), o exame permitiu identificar com segurança o parentesco entre algumas das cópias.

\subsection{Ramo A/B}

O resultado da colação demonstrou que os manuscritos A e B (BNL 12904 e 620 , respectivamente) são estreitamente aparentados, constituindo um primeiro ramo da tradição manuscrita da Crônica de D. Duardos I. Os dois códices se distinguem dos restantes, antes de mais nada, pela letra excepcionalmente clara e uniforme dos amanuenses e pela utilização mais abundante de sinais de pontuação, o que facilita sobremaneira a compreensão do texto e explica grande quantidade das variantes textuais em A e B. Exemplo disso pode ser notado em trecho do capítulo 80: o confronto entre as lições de A e B em oposição às de D e G ilustra claramente as adaptações que resultam do uso de sinais de pontuação. ${ }^{14}$

recurso ao confronto dos chamados 'lugares críticos' (ou 'pontos críticos'), que ajudam a estabelecer não só a dependência de um manuscrito a outro, mas a afinidade ou parentesco de todos os manuscritos da tradição - quando estes manuscritos são numerosos" (1977, p. 93).

14 Nas tabelas que se seguem, a ortografia dos diversos testemunhos foi uniformizada a partir da lição de A e foram ressaltados em itálico os elementos divergentes entre as lições. Em certos casos foram desconsideradas as pequenas variantes textuais que não alteram o elemento que desejamos destacar na colação entre os grupos de manuscritos. Além disso, nos exemplos retirados dos capítulos 11 e 12, as lições de $G$ foram freqüentemente omitidas, por serem completamente divergentes. As peculiaridades desse manuscrito serão discutidas adiante. 
Tabela 1.1: Exemplo de pontuação em A/B (Cap. 80).

\begin{tabular}{|c|c|}
\hline $\mathbf{A} / \mathbf{B}$ & $\mathrm{D}, \mathrm{G}$ \\
\hline $\begin{array}{l}\text {... couzas do mundo. } \\
\text { Depois chamando os grandes de sua } \\
\text { Corte deulhes conta do que em que estava } \\
\text { detreminado, que todos aprovarão, como a } \\
\text { couza que lhe estava melhor. } \\
\text { Ao outro dia, dando reposta ao } \\
\text { Embaixador... }\end{array}$ & $\begin{array}{l}\text {... couzas do mundo tras isto chamando os } \\
\text { grandes de sua Corte deulhes conta do } \\
\text { que em que estava detreminado, que } \\
\text { todos aprovarão como a couza que lhes } \\
\text { melhor estava então dando ao outro dia reposta } \\
\text { ao Embaixador... }\end{array}$ \\
\hline
\end{tabular}

Além disso, há uma série de outras variantes conjuntivas que sugerem o parentesco entre A e B. Vejamos alguns exemplos:

Tabela 1.2: Variantes textuais do ramo A/B.

\begin{tabular}{|c|l|l|l|}
\hline No. & Localiz. & \multicolumn{1}{|c|}{ A/B } & \multicolumn{1}{c|}{ C, D, E, F, G } \\
\hline 1 & Cap. 01 & Via sua caza despojada dos cav aleiros & Via sua caza despovoada dos cavaleiros \\
\hline 2 & Cap. 11 & como se se temerão de grandes males & como se se temerão de males grandes \\
\hline 3 & Cap. 11 & o que no outro capitulo se segue. & o que para o outro capitulo rezervamos. \\
\hline 4 & Cap. 59 & folgava toda via de o ver armado & folgara toda via de o ver armado \\
\hline 5 & Cap. 60 & castello meu a onde agora vamos & castello meu a onde agora bimos \\
\hline 6 & Cap. 61 & daremce os Ultimos abraços & daremce os derradeyros abraços \\
\hline 7 & Cap. 64 & $\begin{array}{l}\text { a o outro dia succedeo ao cavalleiro o que } \\
\text { veremos no capitulo seguinte. }\end{array}$ & $\begin{array}{l}\text { ao qual ao outro dia aconteceo o que no } \\
\text { capitulo seguinte veremos. }\end{array}$ \\
\hline 9 & Cap. 80 & porque era senhora retirada & porque ella era mulher retirada \\
\hline 9 & Cap. 80 & do qual a seu tempo daremos conta. & do qual a seu tempo trataremos. \\
\hline
\end{tabular}

Os exemplos citados acima constituem variantes textuais neutras ou adiáforas, que não alteram o significado das passagens em questão; sua relevância é apenas a de demonstrar o parentesco entre A e B em contraste com as outras cópias do texto. Trata-se da substituição de palavras por termos sinônimos ou equivalentes (como em 1, 5 e 6), da inversão da ordem das palavras (exemplo 2) ou de redações alternativas para sintagmas que compreendem grupos de palavras (8), o que ocorre com freqüência maior nas conclusões dos capítulos (exemplos 3, 7 e 9). No caso do exemplo 4, observa-se que a mudança do tempo verbal é ocasionada pela troca das letras $\mathrm{r} / \mathrm{v}$ : 
como são parecidas, elas muitas vezes são objeto de hesitação por parte dos copistas do texto.

Tabela 1.3: Omissões no ramo A/B.

\begin{tabular}{|c|c|l|l|}
\hline No. & Localiz. & \multicolumn{1}{|c|}{ A/B } & \multicolumn{1}{|c|}{ C, D, E, F, G } \\
\hline 1 & Cap. 12 & $\begin{array}{l}\text { obedecendo à força superior e interior } \\
\text { com que Daliarte os obrigara }\end{array}$ & $\begin{array}{l}\text { obedecendo àquella força interior com que } \\
\text { Daliarte os obrigava }\end{array}$ \\
\hline 2 & Cap. 59 & $\begin{array}{l}\text { das que se alcanção com a experiencia, } \\
\text { especulação, e coriozidade. }\end{array}$ & $\begin{array}{l}\text { das que se alcanção com a especulação e } \\
\text { coriozidade. }\end{array}$ \\
\hline 3 & Cap. 64 & $\begin{array}{l}\text { Melhor quizera eu sahir das minhas } \\
\text { Aventuras, do que vos tendes sahido } \\
\text { desta }\end{array}$ & $\begin{array}{l}\text { Melhor quizera eu sahir das minhas, do que vos } \\
\text { tendes sahido desta }\end{array}$ \\
\hline
\end{tabular}

As omissões de trechos do texto parecem não ser comuns no ramo A/ B. Em quase todos os casos encontrados, elas se restringem à supressão de uma única palavra, normalmente curta e não essencial, como ocorre em 1; quando a omissão abrange expressões ou grupos de palavras, na maior parte dos casos o sentido da passagem também não é afetado, como no exemplo 2.

Tabela 1.4: Interpolações no ramo A/B.

\begin{tabular}{|c|c|c|c|}
\hline No. & Localiz. & $\mathbf{A} / \mathbf{B}$ & C, D, E, F, G \\
\hline 1 & Cap. 01 & $\begin{array}{l}\text { igualdade, e justiça, com que era } \\
\text { governado, tão semelhante á } \\
\text { igualdade, e brandura do Emperador }\end{array}$ & $\begin{array}{l}\text { igualdade, e justiça, com que era governado, } \\
\text { tão semelhante á bondade, e brandura do } \\
\text { Emperador }\end{array}$ \\
\hline 2 & Cap. 11 & $\begin{array}{l}\text { borcados cramezins, que se parecião } \\
\text { ou se fazião parecer de fogo }\end{array}$ & $\begin{array}{l}\text { borcados cramezins, que o fazião parecer de } \\
\text { fogo }\end{array}$ \\
\hline 3 & Cap. 12 & $\begin{array}{l}\text { tornou a dizer a Daliarte: Que não } \\
\text { sei }\end{array}$ & $\begin{array}{l}\text { tornou a dizer para Daliarte: por certo } \\
\text { Daliarte que não sei }\end{array}$ \\
\hline 4 & Cap. 60 & $\begin{array}{l}\text { da quelle trabalho the não podia a } \\
\text { ella vir senão danno }\end{array}$ & $\begin{array}{l}\text { da quelle trato lhe não podia a ella vir senão } \\
\text { danno }\end{array}$ \\
\hline 5 & Cap. 64 & vos não sois tão christã & vos sois tão christã \\
\hline
\end{tabular}

Além de não serem numerosas, a maioria das interpolações encontradas nos manuscritos A e B também não se revestem de outro significado que não o de atestar, uma vez mais, a afinidade entre estes testemunhos. Em 1 e 2, as glosas acrescentadas reforçam o sentido já explicitado na passagem; notese que em 1, além da interpolação de "superior", o ramo A/B caracteriza-se 
pelo uso de "obrigara" onde nas demais cópias há "obrigava". No exemplo 3, a lição de A/B apenas resolve a elipse, pois o termo "aventura" estava subentendido.

Tabela 1.5: Erros no ramo A/B

\begin{tabular}{|c|c|c|c|}
\hline No. & Loc aliz. & A/B & C, D, E, F, G \\
\hline 1 & Cap. 01 & $\begin{array}{l}\text { igualdade, e justiça, com que era } \\
\text { governado, tão semelhante á igualdade, } \\
\text { e brandura do Emperador }\end{array}$ & $\begin{array}{l}\text { igualdade, e justiça, com que era governado, } \\
\text { tão semelhante á bondade, e brandura do } \\
\text { Emperador }\end{array}$ \\
\hline 2 & Cap. 11 & $\begin{array}{l}\text { borcados cramezins, que se parecião ou } \\
\text { se fasião parecer de fogo }\end{array}$ & borcados cramezins, que ofazião parecer de fogo \\
\hline 3 & Cap. 12 & tornou a dizer a Daliarte: Que não sei & $\begin{array}{l}\text { tornou a dizer para Daliarte: por certo Daliarte que } \\
\text { não sei }\end{array}$ \\
\hline 4 & Cap. 60 & $\begin{array}{l}\text { da quelle trabalbo lhe não podia a ella } \\
\text { vir senão danno }\end{array}$ & $\begin{array}{l}\text { da quelle trato lhe não podia a ella vir senão } \\
\text { danno }\end{array}$ \\
\hline 5 & Cap. 64 & vos não sois tão christã & vos sois tão christã \\
\hline
\end{tabular}

A tabela 1.5 apresenta alguns dos casos mais evidentes em que as variantes do ramo $\mathrm{A} / \mathrm{B}$ não devem ser consideradas como adiáforas ou indiferentes, mas sim como erros. ${ }^{15}$ Em 1, houve a troca da palavra "bondade", certamente ecoando a ocorrência do termo "igualdade" pouco antes. Em 2, a lição de A/B parece ser decorrência de um erro de transcrição que, notado a tempo pelo copista, gerou uma adaptação do texto, com o intuito de corrigilo sem necessidade de rasuras. Em 4, houve má leitura; no exemplo 5, a interpolação da palavra "não" altera do sentido da passagem. Em 3, a presença do pronome "que" não se justifica sem o trecho omitido. Ao que tudo indica, este caso representa um saut du même au même, motivado pela repetição do nome de Daliarte. ${ }^{16}$

15 A noção de erro no âmbito do trabalho edótico deve ser precisada. Em princípio, qualquer desvio ou variante textual que divirja do autógrafo ou do que se supõe ser o arquétipo poderia ser tida como errônea. Aqui, porém, qualificaremos como erradas apenas lições que resultarem confusas ou incompreensíveis devido a falhas mecânicas na transmissão do texto. Claro está que, em certos casos, é impossível definir com rigor absoluto a fronteira entre uma lição aceitável e um erro: não há como evitar certo grau de subjetividade nesta matéria. Sobre a revisão do conceito de erro pela edótica moderna, cf. Spaggiari e Perugi, 2004, p. 69-71.

16 O saut du même au même é um tipo de omissão que se explica por uma causa mecânica: a repetição de palavras ou expressões em áreas próximas do texto de base pode levar o copista a saltar o trecho que permeia as duas ocorrências do termo repetido. Cf. West, 2002, p. 29. 
Os exemplos das tabelas 1.1 a 1.5 demonstram a afinidade dos códices A e B. No entanto, embora sejam estreitamente aparentados, esses códices apresentam discrepâncias entre si. Nas tabelas abaixo, os trechos em que há divergências entre A e B serão confrontados também com a lição dos outros manuscritos, a fim de verificar as possíveis origens de tais variantes.

Tabela 1.6: Lições únicas em A e B.

\begin{tabular}{|c|c|l|l|l|}
\hline $\mathbf{N}^{\mathbf{0}}$ & Localiz. & \multicolumn{1}{|c|}{ A } & B & \multicolumn{1}{c|}{ C, D, E, F, G } \\
\hline 1 & Cap. 01 & $\begin{array}{l}\text { todos aquelles senhores } \\
\text { como Oraculos }\end{array}$ & $\begin{array}{l}\text { todos aquelles principes } \\
\text { senhores como Oraculos }\end{array}$ & $\begin{array}{l}e \text { todos aquelles bomens } \\
\text { como Oraculos }\end{array}$ \\
\hline 2 & Cap. 60 & no principio ainda estava? & no principio estava? & no principio estava ainda? \\
\hline
\end{tabular}

Foram encontrados apenas dois casos em que ambas as lições de A e B são únicas, isto é, divergem entre si e também da apresentada pelos outros testemunhos. Nessas passagens, nota-se que a versão de A é a que mais se aproxima das restantes: no primeiro exemplo, o termo "homens" das cópias restantes foi substituído por "senhores" em A, a que o copista de B acrescenta aind a a palavra "príncipes". Em 2, A preserva a palavra "ainda", posto que deslocada, ao passo que $\mathrm{B}$ a omite.

Tabela 1.7: Variantes exclusivas a B.

\begin{tabular}{|c|c|l|l|l|}
\hline $\mathbf{N}^{\mathbf{0}}$ & Localiz. & \multicolumn{1}{|c|}{ A } & B & C, D, E, F, G \\
\hline 1 & Cap. 12 & os acompanharão & os acompanhavão & os acompanharão \\
\hline 2 & Cap. 60 & Aproveitou pouco & Aproveitou-me pouco & Aproveitou pouco \\
\hline 3 & Cap. 80 & de que sua filha era natural & de que era sua filha natural & de que sua filha era natural \\
\hline
\end{tabular}

$\mathrm{Na}$ tabela 1.7 figuram alguns dos casos em que B apresenta pequenas variantes que não constam em A e nos outros códices. Nenhum dos exemplos acima constitui, no entanto, erros que prejudiquem a compreensão do texto. Em 1, a variação na conjugação verbal é explicada pela troca das letras r/v já comentada acima. O exemplo 2 consiste em interpolação de pronome pleonástico. No caso de 3, verifica-se apenas a inversão da ordem das palavras. 
Tabela 1.8: Omissões exclusivas a B.

\begin{tabular}{|c|c|l|l|l|}
\hline $\mathbf{N}^{\mathbf{0}}$ & Localiz. & \multicolumn{1}{|c|}{ A } & \multicolumn{1}{c|}{ B } & \multicolumn{1}{c|}{ C, D, E, F, G } \\
\hline 1 & Cap. 12 & $\begin{array}{l}\text { as Raynhas de Hespanha, e } \\
\text { França a Recindos, e Arnedos, } \\
\text { Sidella a Palmeirim }\end{array}$ & $\begin{array}{l}\text { as Raynhas de Hespanha, e } \\
\text { França a Recindos, Sidella a } \\
\text { Palmeirim }\end{array}$ & $\begin{array}{l}\text { as Raynhas de Hespanha, e } \\
\text { França a Recindos, e Amedos, } \\
\text { Sidella a Palmeirim }\end{array}$ \\
\hline 2 & Cap. 59 & $\begin{array}{l}\text { Ás avessas entendo eu isso } \\
\text { (tornou o outro) porque }\end{array}$ & $\begin{array}{l}\text { Ás avessas entendo eu isso) } \\
\text { porque }\end{array}$ & $\begin{array}{l}\text { Ás avessas entendo eu isso } \\
\text { tornou o outro porque }\end{array}$ \\
\hline 3 & Cap. 62 & $\begin{array}{l}\text { partirão de sua caza todos tres } \\
\text { juntos para Constantinopla }\end{array}$ & partirão para Constantinopla & $\begin{array}{l}\text { partirão de sua caz̃a todos tres } \\
\text { juntos para Constantinopla }\end{array}$ \\
\hline
\end{tabular}

Nos capítulos cotejados, não há passagens em que A apresente lacunas no texto em comparação com B; foram encontrados apenas exemplos de omissões de partes do texto exclusivas a B. Ainda que em nenhum dos casos acima o trecho omitido seja essencial para a inteligibilidade da frase,${ }^{17}$ os exemplos permitem concluir que: a) entre A e B, o primeiro apresenta lição mais próxima à das demais cópias, conforme foi sugerido acima; b) A não pode ter sido copiado de B.

Tabela 1.9: Erros exclusivos a B.

\begin{tabular}{|c|c|c|c|c|}
\hline $\mathbf{N}^{\circ}$ & Localiz. & $\mathbf{A}$ & B & C, D, E, F, G \\
\hline 1 & Cap. 11 & $\begin{array}{l}\text { não se vião muy } \\
\text { distintamente }\end{array}$ & não se vião muy distantemente & $\begin{array}{l}\text { não se vião muy } \\
\text { distintamente }\end{array}$ \\
\hline 2 & Cap. 12 & $\begin{array}{l}\text { querendolhe huns, e outros } \\
\text { bejar a mão, não a deu senão } \\
\text { a os nettos }\end{array}$ & $\begin{array}{l}\text { querendolhe huns, e outros } \\
\text { bejar a mão, a deu senão dos } \\
\text { nettos }\end{array}$ & $\begin{array}{l}\text { querendolhe huns, e } \\
\text { outros bejar a mão, não a } \\
\text { deu senão a os nettos }\end{array}$ \\
\hline 3 & Cap. 60 & porque vou vendo que vos & porque vos vendo que vos & porque vou vendo que vos \\
\hline 4 & Cap. 62 & $\begin{array}{l}\text { Resoluto nisto chamou } \\
\text { Ardellio, e disselbe: Ardellio } \\
\text { amigo, mal me ouzaria eu }\end{array}$ & $\begin{array}{l}\text { Resultou nisto chamou } \\
\text { Ardellio, amigo e disselhe mal } \\
\text { me ouzaria eu }\end{array}$ & $\begin{array}{l}\text { Resoluto nisto chamou } \\
\text { Ardellio, e disselhe: Ardellio } \\
\text { amigo, mal me ouzaria eu }\end{array}$ \\
\hline
\end{tabular}

O códice B também apresenta alguns erros que não se encontram em A. Trata-se da troca de palavras por outras que, embora semelhantes, não

17 O único exemplo em que a lição de B resulta errada é o segundo, em que o copista manteve apenas um dos parênteses do trecho que saltou. A presença do parêntese pode indicar que B foi copiado de A ou de um outro manuscrito perdido em que a expressão "tornou o outro" também estaria entre parênteses. Observe-se que dentre as cópias conhecidas do texto, entretanto, a única que apresenta parênteses nesta passagem é justamente A. 
fazem sentido no contexto (exemplos 1, 3 e no início do exemplo 4), da omissão da palavra "não", que gera uma tentativa de adaptação mal-sucedida (2) e de um salto provavelmente motivado pela repetição do nome de Ardélio (exemplo 4).

Embora pouco numerosos, os erros exclusivos a B são mais freqüentes que os do códice A, que figuram na tabela abaixo.

Tabela 1.10: Erros exclusivos a A.

\begin{tabular}{|c|c|l|l|l|}
\hline $\mathbf{N}^{\mathbf{0}}$ & Localiz. & \multicolumn{1}{|c|}{$\mathbf{A}$} & $\mathbf{B}$ & \multicolumn{1}{c|}{$\mathbf{C ,} \mathbf{D}, \mathbf{E}, \mathbf{F}, \mathbf{G}$} \\
\hline 1 & Cap. 12 & aquellas senhores estavão & aquellas senhoras estavão & aquellas senhoras estavão \\
\hline 2 & Cap. 60 & $\begin{array}{l}\text { ás dividas em que à primeira } \\
\text { confiança }\end{array}$ & $\begin{array}{l}\text { ás duvidas em que à primeira } \\
\text { confiança }\end{array}$ & $\begin{array}{l}\text { ás duvidas em que à } \\
\text { primeira confiança }\end{array}$ \\
\hline
\end{tabular}

A tabela 1.10 apresenta os dois únicos casos encontrados de erros do códice A que não se repetem em B. Admitindo a hipótese de que B tenha sido copiado de A, o primeiro exemplo poderia facilmente ter sido notado e corrigido pelo copista de B, inclusive pela presença do pronome feminino "aquellas", que foi mantido em A. No entanto, em 2 é menos provável que isso tenha ocorrido, pois a troca de “dúvidas" por "dívidas" seria um erro dificilmente identificável pelo copista de B. ${ }^{18}$

Findo o exame do ramo A/B, estamos em condições de sistematizar algumas conclusões. Em primeiro lugar, nota-se que as numerosas variantes comuns e exclusivas a A e B (cf. as tabelas 1.1 a 1.5) caracterizam a afinidade entre ambos, sendo que a maior parte delas consiste em lições adiáforas. Por outro lado, a quantidade de discrepâncias exclusivas a B permite supor que a lição de A seja a mais confiável, hipótese reforçada pela constatação da impossibilidade de A ter sido copiado a partir de $\mathrm{B}$, visto que esse manuscrito apresenta lacunas em comparação com aquele. Embora as evidências analisadas permitam supor A seja o antígrafo de B (ou seja, que A tenha sido o texto de base a partir da qual B foi copiado), o último exemplo da tabela 1.10 parece desautorizar tal conclusão, a menos que estejamos diante de um caso de contaminação. ${ }^{19}$ Assim, embora inclinados a admitir a tese de B ser cópia de A, por prudência adotamos como possível também a hipótese de ambos os códices procederem de um antecedente comum perdido.

Em síntese, as duas possibilidades relativas ao ramo A/B poderiam ser representadas das seguintes formas:

18 Note-se que D apresenta o mesmo erro. Trata-se, no entanto, de uma provável coincidência, uma vez que, conforme veremos adiante, $\mathrm{D}$ não apresenta afinidades significativas com A. 
A

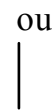

B $\alpha$ (subarquétipo perdido)

$\mathrm{A}$

B

\subsection{Ramo E/F}

Outro ramo bem caracterizado na tradição manuscrita da Crônica de D. Duardos I é o composto pelos códices E e F. Diferentemente do que sucedeu no ramo A/B, no entanto, o parentesco entre $\mathrm{E}$ e $\mathrm{F}$ é caracterizado por um número maior de erros comuns a ambos testemunhos. O códice E (TT 1773, $1^{\text {a }}$ parte), dentre todos, é o de mais difícil leitura, não apenas pelo tamanho reduzido da letra, como também pelo estado dos fólios, que se encontram muito escurecidos. $\mathrm{O}$ amanuense que o copiou utiliza grande quantidade de abreviações e possui hábitos ortográficos arcaizantes que o singularizam, visíveis sobretudo nas terminações em -ão, sempre grafadas por ele com -am: é o caso de nam (= não) e rezam (= razão), por exemplo, mas também de poderiam (= poderião, nos outros códices). ${ }^{20}$ Já o códice F (BNL 483), o mais recente de todos, embora seja redigido com letra muito clara e esteja melhor conservado, apresenta numerosos erros de cópia.

Conforme procedimento adotado para o exame do ramo A/B, iniciaremos pelos exemplos das variantes conjuntivas do ramo $\mathrm{E} / \mathrm{F}$.

Tabela 2.1: Variantes textuais do ramo E/F.

\begin{tabular}{|c|c|l|l|}
\hline No. & Localiz. & \multicolumn{1}{|c|}{ E/F } & \multicolumn{1}{|c|}{ A, B, C, D, G } \\
\hline 1 & Cap. 01 & em quanto os animos se socegão & em quanto os animos se assegurão \\
\hline 2 & Cap. 01 & $\begin{array}{l}\text { se começarão a fazer prestes com suas } \\
\text { mulheres e filhas os que os tinhão para } \\
\text { Constantinopla }\end{array}$ & $\begin{array}{l}\text { se começarão a faztantinopla, com suas mulheres e filhas (os } \\
\text { que os tinbão) }\end{array}$ \\
\hline 3 & Cap. 11 & onde a cerpe se sumira & onde a cerpe se sumergira \\
\hline 4 & Cap. 62 & vierão ter com Barciliano, e Trineo & vierão ter com Trineo, e Barciliano \\
\hline
\end{tabular}

19 Não era incomum que amanuenses compulsassem mais de um manuscrito ao realizar sua cópia, selecionando as lições que lhes parecessem melhores. De qualquer modo, para sustentar esta hipótese seria preciso reunir mais elementos. Sobre a contaminação, cf. Spaggiari e Perugi, 2004, p. 41-42.

20 É preciso observar que as peculiaridades ortográficas de E devem ser imputadas a causas meramente acidentais, como a hábitos do amanuense, e não podem servir para suposições quanto à possível antigüidade da cópia, visto que o códice está datado de 1668 - informação cuja autenticidade não há motivos para questionar. 
As variantes textuais de $\mathrm{E} / \mathrm{F}$ são de tipos semelhantes às analisadas no ramo A/B: em grande parte dos casos resumem-se à substituição de palavras por outras, sinônimas ou equivalentes (exemplos 1 e 3). Em 2 e 4 ocorre a simples alteração da ordem das palavras. São variações pouco significativas para além do fato de atestarem a afinidade entre E e F.

Tabela 2.2: Omissões no ramo E/F.

\begin{tabular}{|c|c|l|l|}
\hline No. & Localiz. & \multicolumn{1}{|c|}{ E/F } & \multicolumn{1}{|c|}{ A, B, C, D, G } \\
\hline 1 & Cap. 01 & $\begin{array}{l}\text { Em que se da conta da vida, que fazia o } \\
\text { Emperador e os outros Principes }\end{array}$ & $\begin{array}{l}\text { Em que se da conta da vida, que fazia o } \\
\text { Emperador Primaleão e os outros Principes }\end{array}$ \\
\hline 2 & Cap. 11 & aquelle extraordinario incendio & aquelle tão extraordinario incendio \\
\hline 3 & Cap. 60 & escreveume hua carta, e tantas outras & $\begin{array}{l}\text { escreveume hua carta, e outra carta e tantas } \\
\text { outras }\end{array}$ \\
\hline
\end{tabular}

Outro tipo de variantes que comprovam a consangüinidade dos códices E e F são as omissões de palavras ou expressões breves. Como é compreensível, as palavras omitidas são normalmente curtas ou dispensáveis para a intelecção da passagem em questão. O mesmo sucede com a omissão de sintagmas ou expressões: é o caso do exemplo 3, que pode ser explicado pela repetição do termo "carta", configurando outro caso do saut du même au même.

Tabela 2.3: Erros no ramo E/F.

\begin{tabular}{|c|c|c|c|}
\hline No. & Localiz. & $\mathrm{E} / \mathrm{F}$ & $A, B, C, D, G$ \\
\hline 1 & Cap. 12 & Querẽdo Polynardo seu bejarlha logo & querẽdo Polynardo seu tio bejarlha logo \\
\hline 2 & Cap. 59 & $\begin{array}{l}\text { começou a caminhar por aquelles campos } \\
\text { seguindo os dos Gabões, seguramente } \\
\text { delle entrarão na charneca }\end{array}$ & $\begin{array}{l}\text { começou a caminhar por aquelle campo } \\
\text { seguindo os dos Gabões, e sabindo } \\
\text { seguramente delle entrarão na charneca }\end{array}$ \\
\hline 3 & Cap. 60 & àquillo de que a preçoadia antes & à quillo de que a antes a dissuadia \\
\hline 4 & Cap. 61 & $\begin{array}{l}\text { lhe declarava quam entregue } e \text { pobre } \\
\text { homem vivia }\end{array}$ & $\begin{array}{l}\text { lhe declarava quam entregue } o \text { pobre homem } \\
\text { vivia }\end{array}$ \\
\hline 5 & Cap. 62 & athe chegar á raiz do outro & athe chegar á raiz do outeiro \\
\hline 6 & Cap. 64 & $\begin{array}{l}\text { será razão que o vio desta tribuna e da } \\
\text { camareira Mor }\end{array}$ & $\begin{array}{l}\text { será razão que saibais que o uzo desta tribuna be } \\
\text { da camareira Mor }\end{array}$ \\
\hline 7 & Cap. 80 & Embaixador de Dramuziando & Embaixador, $e$ Dramuziando \\
\hline
\end{tabular}


Os erros comuns ao grupo E/F são mais freqüentes que os do ramo anterior. Em 1, E e F omitem a palavra "tio", sem a qual a frase fica sem sentido. Em 2, além do plural em "aquelles campos", que seria uma variação pouco significativa, omitiu-se "e sahindo", com o que se compromete o significado do resto da frase. A troca de palavras em 3, 4, 5, 6 e 7 (algumas delas simples preposições) também resulta em frases incompreensíveis. ${ }^{21}$

Em suma, os exemplos das tabelas 2.1 a 2.3 são suficientes para comprovar o parentesco entre E e F. Mas, assim como ocorre no caso do ramo A/ $\mathrm{B}$, os códices $\mathrm{E}$ e $\mathrm{F}$ não são idênticos. A fim de compreender a relação entre eles, será preciso analisar brevemente as discrepâncias que os diferenciam. Sendo que a maioria das variantes são exclusivas a F, é pelo exame delas que iniciaremos.

Tabela 2.4: Variantes exclusivas a F.

\begin{tabular}{|c|c|c|c|c|}
\hline $\mathbf{N}^{\mathbf{o}}$ & Localiz. & $\mathbf{E}$ & F & $\mathrm{A}, \mathrm{B}, \mathrm{C}, \mathrm{D}, \mathrm{G}$ \\
\hline 1 & Cap. 01 & $\begin{array}{l}\text { os corações de Primaleão e de } \\
\text { seus vassallos }\end{array}$ & $\begin{array}{l}\text { o coracãa de Primaleão e } \\
\text { de seus vassallos }\end{array}$ & $\begin{array}{l}\text { os corações de Primaleão e de } \\
\text { seus vassallos }\end{array}$ \\
\hline 2 & Cap. 12 & $\begin{array}{l}\text { pois no sobresalto deste dia vos } \\
\text { temos sido companbeiros, e no } \\
\text { trabalho de vir aqui buscallos } \\
\text { nos fas nos não fas nimguem } \\
\text { companhia. }\end{array}$ & $\begin{array}{l}\text { pois nos sobresaltos deste } \\
\text { dia vos temos feito } \\
\text { companbia, e no trabalho } \\
\text { de vir aqui buscallos nos } \\
\text { não fas nimguem } \\
\text { companhia. }\end{array}$ & $\begin{array}{l}\text { pois no sobresalto deste dia vos } \\
\text { temos sido companheiros, e no } \\
\text { trabalho de vir aqui buscallos } \\
\text { nos não fas nimguem } \\
\text { companhia. }\end{array}$ \\
\hline 3 & Cap. 59 & quando estava na agoa & quando estava na lagoa & quando estava na agoa \\
\hline 4 & Cap. 60 & o que lhe eu divia & o que lhe eu diztia & o que lhe eu divia \\
\hline 5 & Cap. 80 & $\begin{array}{l}\text { de se Mostrarem quando } \\
\text { cuidão }\end{array}$ & $\begin{array}{l}\text { de demonstrarem quando } \\
\text { cuidão }\end{array}$ & $\begin{array}{l}\text { de se Mostrarem quando } \\
\text { cuidão }\end{array}$ \\
\hline
\end{tabular}

As alterações exemplificadas acima foram introduzidas pelo copista de $\mathrm{F}$, uma vez que não correspondem à lição de $\mathrm{E}$, que nesses casos é idêntica à dos demais códices. A única exceção é a do exemplo 2, onde há uma repetição indevida em E ("nos fas nos não fas"), que aliás seria facilmente identificável pelo copista de F, caso ele tenha utilizado E como base para sua cópia. ${ }^{22}$ Os

21 No exemplo 5, é possível que a origem do erro seja uma abreviação da palavra "outeiro" no antígrafo, não percebida pelo copista. Em 3, os ms. C e D apresentam ordem das palavras mais próxima da do ramo $\mathrm{E} / \mathrm{F}$, ainda que não compartilhem o erro deste ramo: "aquillo de que a dissuadia antes".

22 Na passagem referente ao exemplo 3, A apresenta uma repetição indevida da palavra "deste": "no sobresalto deste [[deste]] dia". 
exemplos 3, 4 e 5 apresentam alterações que não prejudicam a intelecção do trecho.

Tabela 2.5: Erros exclusivos a F.

\begin{tabular}{|c|c|c|c|c|}
\hline $\mathbf{N}^{\circ}$ & Localiz. & $\mathbf{E}$ & F & $\mathrm{A}, \mathrm{B}, \mathrm{C}, \mathrm{D}, \mathrm{G}$ \\
\hline 1 & Cap. 01 & $\begin{array}{l}\text { couza que os Princepes, que } \\
\text { entrão de novo em seus } \\
\text { estados necessariamente } \\
\text { ande fazer. Acomodar-se, } \\
\text { digo, ao governo }\end{array}$ & \begin{tabular}{|lr} 
couza que os Princepes, \\
que entrão de novo em \\
seus rados \\
necessariamente $r$ ande \\
acomodar-se ao governo
\end{tabular} & $\begin{array}{l}\text { couza que os Princepes, que } \\
\text { entrão de novo em seus } \\
\text { estados necessariamente ande } \\
\text { fazer. Acomodar-se, digo, ao } \\
\text { govemo }\end{array}$ \\
\hline 2 & Cap. 12 & $\begin{array}{l}\text { que lhe entretinha o cuidado } \\
\text { de Sua Alteja }\end{array}$ & $\begin{array}{l}\text { que the entretinha o } \\
\text { cuidado de } S . A .\end{array}$ & $\begin{array}{l}\text { que lhe entretinha o cuidado } \\
\text { de sua Altea }\end{array}$ \\
\hline 3 & Cap. 59 & $e u$ lhe respondeu elle & bum lhe respondeu elle & $E u$ (lhe respondeu elle) \\
\hline 4 & Cap. 59 & vamos buscar os rocins & vamos buscar as raz̃ões & vamos buscar os rocins \\
\hline 5 & Cap. 60 & $\begin{array}{l}\text { cazarãome meus Pais com } \\
\text { vosco }\end{array}$ & $\begin{array}{l}\text { canzarãome meus Pais } \\
\text { com vosco }\end{array}$ & $\begin{array}{l}\text { cazarãome meus Pais com } \\
\text { vosco }\end{array}$ \\
\hline 6 & Cap. 62 & $\mathrm{~m}$ as deixandoo logo & mas deitandoo logo & mas deixandoo $\log 0$ \\
\hline 7 & Cap. 64 & puxando pella das praticas & puxando pellas praticas & puxando pella das praticas \\
\hline 8 & Cap. 64 & $\begin{array}{l}\text { ás tendas de ElRey que a } \\
\text { porta de hua dellas }\end{array}$ & $\begin{array}{l}\text { ás tendas de ElRey que } \\
\text { apartada de hua dellas }\end{array}$ & $\begin{array}{l}\text { ás tendas de ElRey que } a \\
\text { porta de hua dellas }\end{array}$ \\
\hline
\end{tabular}

São numerosos os erros de cópia de $\mathrm{F}$ que não estão presentes em E. $\mathrm{Na}$ maioria dos casos, trata-se de uma troca indevida de palavras (exemplos 3 , 4, 5, 6 e 8) ou da omissão de uma palavra a prejudicar a clareza do texto (7).

No exemplo 2, o nome da personagem Altea foi confundido com a palavra "Alteza": daí a abreviação em F ("S. A." é abreviação comum de "Sua Alteza"). Caso F tenha sido copiado de E, o equívoco poderia ser explicado pelo fato de este códice grafar o nome com a semivogal $j$.

Na tabela acima merece atenção particular o exemplo 1, em que a omissão do verbo "fazer" em F torna a frase incompreensível; é preciso notar, contudo, que quanto à falta do verbo "digo", parece ter havido uma correção por parte do amanuense, posto que a inclusão de glosa iniciada por "digo" era modo habitual com que os copistas da época faziam correções evitando a rasura do texto. O que parece ter ocorrido nesse caso é que uma emenda feita em nível muito alto da tradição manuscrita (talvez no próprio autógrafo) acabou por ser inadvertidamente incorporada ao texto, transmitindo-se a todos os testemunhos conhecidos. As únicas exceções são os manuscritos F e G: no 
caso do primeiro, pelo que a esta altura já é possível concluir dos exemplos analisados, não é provável que se trate de um representante de nível mais alto da tradição, ou mesmo de cópia direta de códice que não contivesse a emenda. Quanto a $G$, sua situação no estema será discutida adiante.

Tabela 2.6: Lições únicas em $\mathrm{E}$ e F.

\begin{tabular}{|c|c|c|c|c|}
\hline $\mathbf{N}^{\circ}$ & Localiz. & $\mathbf{E}$ & $\mathbf{F}$ & $\mathrm{A}, \mathrm{B}, \mathrm{C}, \mathrm{D}, \mathrm{G}$ \\
\hline 1 & Cap. 12 & $\begin{array}{l}\text { pois não pode deixar de ser a } \\
\text { criação este Donzel Floris }\end{array}$ & $\begin{array}{l}\text { pois não pode deixar de } \\
\text { ser a criação este de } \\
\text { Floris }\end{array}$ & $\begin{array}{l}\text { pois não pode deixar de ser } \\
\text { criação. Este be } D \text {. Floris }\end{array}$ \\
\hline 2 & Cap. 12 & $\begin{array}{l}\text { velassem as armas para que } a \\
o \text { foss? }\end{array}$ & $\begin{array}{l}\text { velassem as armas para } \\
\text { que } o \text { foss? }\end{array}$ & $\begin{array}{l}\text { velassem as armas para que } \\
\text { o outro dia o foss? }\end{array}$ \\
\hline 3 & Cap. 60 & $\begin{array}{l}\text { deixe de vos obedecer, digo } \\
\text { offerecer a obediência }\end{array}$ & $\begin{array}{l}\text { deixe de vos obedecer, ou } \\
\text { offerecer a obediencia }\end{array}$ & $\begin{array}{l}\text { deixe de vos offerecer } \\
\text { obediencia }\end{array}$ \\
\hline 4 & Cap. 61 & $\begin{array}{l}\text { perdeu a desculpa que podia } \\
\text { ter dando, porque a emsesão } \\
\text { foy acto da liberdade } \\
\text { forçada, e a promessa da } \\
\text { vontade livre, e dada esta } \\
\text { deffença }\end{array}$ & $\begin{array}{l}\text { perdeu a desculpa que } \\
\text { podia tardando, porque a } \\
\text { inceção foy acto da } \\
\text { liberdade forçada, e a } \\
\text { promessa da vontade livre, } \\
\text { e dada esta deffença }\end{array}$ & $\begin{array}{l}\text { perdeu a desculpa que pod } \\
\text { ter dando, porque a conceç, } \\
\text { foy acto da liberdade forçad } \\
\text { e a promessa da vontac } \\
\text { livre, e dada esta differença }\end{array}$ \\
\hline 5 & Cap. 80 & $\begin{array}{l}\text { o que mais convinha á } \\
\text { honrra de sua filha, e } \\
\text { autolidade de seus vassallos }\end{array}$ & $\begin{array}{l}\text { o que mais convinha á } \\
\text { honrra de sua filha, e } \\
\text { autoridade de seus vassallos }\end{array}$ & $\begin{array}{l}\text { o que mais convinha } \\
\text { honrra de sua filha, e } \\
\text { utilidade de seus vassallos }\end{array}$ \\
\hline
\end{tabular}

A tabela 2.6 apresenta os casos em que as variantes dos códices em questão divergem entre si. De modo geral, são possíveis duas explicações para a presença desses erros: se admitirmos que $\mathrm{F}$ tenha sido copiado de $\mathrm{E}$ - como sugere a maior quantidade de erros de cópia em $\mathrm{F}$-, as variantes poderiam ser explicadas por equívocos cometidos pelo amanuense do códice E a que se seguiram em certos casos emendas nem sempre bem-sucedidas por parte do copista de F; por outro lado, caso E e F tenham sido copiados a partir de um mesmo manuscrito, as lições desses códices poderiam ser resultado de falhas existentes no antecedente comum. Uma vez que, como já foi ressaltado, E apresenta menos variantes e erros, a hipótese mais provável é a primeira - ou seja, que E seja o antígrafo de F.

O único exemplo que não parece confirmar esta afirmação é o primeiro, pois nesse caso a lição de F é a que mais se aproxima da dos outros testemunhos; de toda forma, é também possível que o copista de F tenha emendado a lição de E, reaproximando-se da lição correta. Em 2, o salto de trecho do texto é mais visível em E, ao passo que o copista de F parece ter 
notado o problema e ter tentado corrigi-lo. O exemplo 3 retrata novamente o uso de "digo" exercendo a função de introduzir a correção de um erro de cópia em E ou no subarquétipo do ramo E/F, o que deve ter sido notado pelo copista de F. Em 4, a lição de E é a mais próxima da dos demais códices, embora ela também apresente problemas. O exemplo 5 também parece se explicar por um erro de cópia ocorrido em E e transmitido a F: neste caso, a união do artigo com a palavra "utilidade" grafada incorretamente pode ter sido o motivo da emenda por parte do amanuense de F.

Tabela 2.7: Erros exclusivos a E.

\begin{tabular}{|c|c|l|l|l|}
\hline $\mathbf{N}^{\mathbf{o}}$ & Localiz. & \multicolumn{1}{|c|}{$\mathbf{E}$} & \multicolumn{1}{|c|}{$\mathbf{F}$} & \multicolumn{1}{c|}{ A, B, C, D, G } \\
\hline 1 & Cap. 60 & filhos, entre os que dais & filhos, entre os quais & filhos, entre os quais \\
\hline 2 & Cap. 60 & $\begin{array}{l}\text { a the para não ser mais julgado } \\
\text { de Daraja mostrar hu pouco de } \\
\text { mais sentimento }\end{array}$ & $\begin{array}{l}\text { a the para não ser mal } \\
\text { julgado de Daraja mostrar } \\
\text { hu pouco de sentimento mais }\end{array}$ & $\begin{array}{l}\text { a the para não ser mal julgado } \\
\text { de Daraja mostrar hu pouco de } \\
\text { maimento }\end{array}$ \\
\hline
\end{tabular}

Os erros de transcrição exclusivos a E encontrados foram apenas dois, ambos no capítulo 60. Ainda que o primeiro pudesse ser identificado pelo copista de F, caso ele estivesse utilizando como base o códice E (e, com efeito, a passagem parece corrigida em F), é menos provável que o mesmo sucedesse com o segundo exemplo. ${ }^{23}$

Encontramo-nos pois em situação semelhante à verificada com relação ao ramo A/B: apesar de serem vários os indícios que apontam para a hipótese de E ser o antígrafo de F, dois detalhes de caráter duvidoso (ex. 1 da tabela 2.6 e ex. 2 da tabela 2.7) parecem desaconselhar essa conclusão. Dessa forma, por cautela admitimos a possibilidade de E e F serem cópias de um mesmo subarquétipo perdido, embora estejamos inclinados a considerar F como cópia de E, pelos diversos motivos anteriormente apontados. Formulamos mais uma vez, portanto, duas hipóteses para a representação do estema deste ramo:

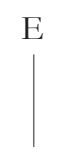

$\mathrm{F}$ ou

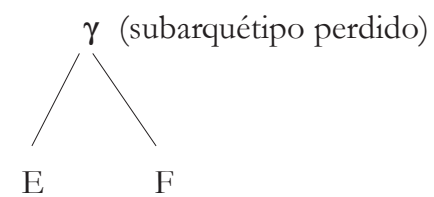

23 A lição de B apresenta um erro nessa passagem, pois falta-lhe a palavra "não", o que deixa a frase sem sentido: trata-se de mais um elemento a reforçar as conclusões anteriormente expostas acerca dessa cópia. 


\subsection{Os códices C E D}

Afora os códices já examinados, os demais não apresentam afinidades tão estreitas que permitam concluir pela existência de novos ramos da tradição manuscrita. Com efeito, as evidências de uma suposta proximidade entre $\mathrm{C}$ e D são muito mais tênues do que as existentes entre $\mathrm{A}$ e $\mathrm{B}$ ou entre E e F.

Do que foi exposto até o momento, nota-se que as lições de C e D ora se aproximam do ramo A/B (quando foram encontradas variantes exclusivas a $\mathrm{E}$ e $\mathrm{F}$ ), ora do ramo $\mathrm{E} / \mathrm{F}$ (nos casos das variantes que caracterizam A e B). No entanto, apesar de C e D ocuparem a mesma posição "intermediária" entre os ramos acima descritos, foram encontradas numerosas variantes exclusivas a cada um dos códices em questão. Por isso, eles serão examinados em separado, antes de verificarmos os indícios que apontam para a ligação entre ambos.

O códice BNL 658 (C) é o único que foi copiado por duas mãos. A mudança de punho (que ocorre, como já observamos, em meio ao capítulo 64) levanta questões que não podem ser ignoradas para a correta avaliação das variantes apresentadas no códice. Qual o motivo da troca de copistas: trata-se simplesmente de uma substituição ocorrida no decorrer do trabalho ou o manuscrito atual é resultado da junção de partes de dois códices originalmente independentes? Nesse caso, os amanuenses basearam-se num mesmo antígrafo ou tomaram por base manuscritos diferentes?

O exame das marcas d'água demonstra que na confecção desse códice foram utilizados papéis de procedência variada; há inclusive um trecho (fols. 115 a 120) em que foi aproveitado um papel de qualidade inferior e completamente diversa da dos demais. Isso pode indicar que o manuscrito tenha sido redigido para uso privado e que, por isso, não foi dada grande atenção à apresentação do texto; numa cópia como essa, presumivelmente feita com pressa e valendo-se dos recursos mais à mão, não estranha a mudança de letra. Além disso, o fato de alguns fólios do trecho copiado pelo segundo punho apresentarem marcas d'água iguais a algumas das encontradas nos fólios utilizados pelo primeiro copista sugere que os dois amanuenses trabalharam em períodos e regiões aproximados. Tudo indica, portanto, não ter havido a junção de partes de dois manuscritos preexistentes; o códice $C$ parece ser cópia feita sem grande esmero e que, por motivo desconhecido, foi concluída por um amanuense diferente daquele que havia iniciado o trabalho. Com efeito, ao menos no trecho analisado, não foram encontrados elementos relevantes que permitissem supor a utilização de outro antígrafo por parte do segundo amanuense. Ainda assim, por motivo de clareza, nas 
tabelas que se seguem os exemplos retirados do trecho transcrito pelo segundo punho (pertencentes ao final do capítulo 64 e ao capítulo 80) foram assinalados com asterisco.

Tabela 3.1: Lições Adiáforas de C.

\begin{tabular}{|c|c|l|l|}
\hline No. & Loliz. & \multicolumn{1}{|c|}{ C } & \multicolumn{1}{|c|}{ A, B, D, E, F, G } \\
\hline 1 & Cap. 01 & reduzida aquella cidade & redurido aquella cidade \\
\hline 2 & Cap. 11 & $\begin{array}{l}\text { que se não vião huns a os Outros, o qual } \\
\text { acabado }\end{array}$ & $\begin{array}{l}\text { que se não vião huns a os Outros, acabado o } \\
\text { qual }\end{array}$ \\
\hline 3 & Cap. 12 & os com que serrava o numero & os com que se serrava o numero \\
\hline 4 & Cap. 61 & huns cinquo troncos & huns troncos \\
\hline $5^{*}$ & Cap. 64 & e remetendo a o do Sol & e remeteu a o do Sol \\
\hline $6^{*}$ & Cap. 80 & ponderasse Sua Alteza se convinha & ponderasse Sua Alteza bem se convinha \\
\hline
\end{tabular}

$\mathrm{O}$ manuscrito $\mathrm{C}$ distingue-se pela pequena quantidade de variantes que lhe são exclusivas, em comparação com os ramos anteriormente examinados. O exemplo 1 consiste na concordância do particípio com o objeto, que ainda era comum na transição dos séculos XVI e XVII ${ }^{24}$ e em 2, há inversão da ordem das palavras. Os exemplos restantes consistem na troca de formas verbais por outras igualmente possíveis nos respectivos contextos (5) ou em pequenas omissões ou interpolações (em 3, 4, e 6).

Tabela 3.2: Erros do códice C.

\begin{tabular}{|c|l|l|l|}
\hline No. & Loliz. & \multicolumn{1}{|c|}{ C } & \multicolumn{1}{c|}{ A, B, D, E, F, G } \\
\hline 1 & Cap. 12 & então levandoo & então levantandoo \\
\hline 2 & Cap. 59 & tirarlho por força, aforça que & tirarlho por força, a fóra que \\
\hline 3 & Cap. 60 & que nos mostrou a ambos & que nos matou a ambos \\
\hline 4 & Cap. 62 & acontecer al || a Recindos & acontecer algũ dezastre a Recindos \\
\hline $5 *$ & Cap. 80 & Dramusiando, Amelio, Palmeirim Frenellio & $\begin{array}{l}\text { Dramusiando, Recindos, Amedos, Palmeirim } \\
\text { Frenellio }\end{array}$ \\
\hline
\end{tabular}

24 "Os particípios, que, com os verbos ter e haver, constituem locuções verbais ativas, concordavam em gênero e número com o objeto direto do verbo; essa prática parece perdurar durante todo o século XVI" (Paiva, 1988, p. 59-60). Note-se que é este o caso em questão, pois a frase completa (que é a primeira do capítulo 01), diz: "Redificado tinha o Emperador Primaleão os muros de Constantinopla e redurido aquella cidade...". 
Foram encontrados também poucos erros em C. A troca de "levantando-o" por "levando-o" em 1 é caso de haplografia. Em 2 e 3 ocorrem trocas de palavras por erros de leitura ou por associações mentais do copista. ${ }^{25}$ No exemplo 5, o nome de Arnedos é grafado incorretamente, devido à proximidade com o nome de Frenélio; ${ }^{26}$ algo parecido ocorre em 2, onde a palavra "força" ecoa na seguinte. E, finalmente, o pequeno salto no texto verificado em 4 explica-se pela mudança de fólio (assinalada por duas barras).

O códice D (BNL 6828), ao contrário de C, apresenta numerosas variantes e erros do amanuense, apesar de ser redigido com letra clara e uniforme. $\mathrm{O}$ traço distintivo dessa cópia é o uso de sinais de pontuação incomuns: dois traços perpendiculares $(/ /)$ para indicar o fim de frase ou mudança de parágrafo e outro sinal, assemelhado a um til $(\sim)$ ou a um ponto de interrogação deitado, para indicar a interrogação. Pelo que verificamos, contudo, o emprego desses sinais, além de parcimonioso, não abrange a totalidade da cópia.

Tabela 3.3: Lições Adiáforas de D.

\begin{tabular}{|c|c|l|l|}
\hline No. & Localiz. & \multicolumn{1}{|c|}{ D } & \multicolumn{1}{c|}{ A, B, C, E, F, G } \\
\hline 1 & Cap. 01 & pezavalhe de os ter deixado & pezavalhe de lhos ter deixado \\
\hline 2 & Cap. 60 & hua filha fermoza muito & hua filha deponca idade, fermoza muito \\
\hline 3 & Cap. 60 & com estas licenças & com estas ližnjas \\
\hline 4 & Cap. 61 & $\begin{array}{l}\text { os moradores della ficarão quietos } \text { e ficarão } \\
\text { contentes como temos contado }\end{array}$ & $\begin{array}{l}\text { os Moradores della ficarão quietos como } \\
\text { temos contado }\end{array}$ \\
\hline 5 & Cap. 62 & Encontrarão-se aquelles Cavalleiros & Em cheio se encontrarão aquelles Cavalleiros \\
\hline 6 & Cap. 64 & A fé epor esta cruz que sois vos mui letrada & A fé que sois vos muy letrada \\
\hline 7 & Cap. 80 & Ponderando tamb? o seu & Poderava tamb? o seu \\
\hline
\end{tabular}

Os exemplos referidos na tabela 3.3 ilustram alguns dos numerosos casos em que o manuscrito D apresenta variantes adiáforas: trata-se da subs-

25 Note-se que no caso do exemplo 3, o termo matou foi corrigido pelo copista de A, o que pode ser indicativo do fato desta passagem apresentar algum problema de transmissão também no antígrafo deste manuscrito, o que pode sugerir a existência de alguma emenda ou correção em nível mais alto da tradição, comum ao ramo A/B e a C. As possíveis relações entre A/B e C serão discutidas a seguir.

26 Há erro nesta mesma passagem em D: "Dramusiando, Recindos, e Arnaldo, Arnedos...": o nome acrescentado não corresponde a nenhum personagem da obra. 
tituição de palavras ou da redação divergente de trechos curtos, sem prejuízo do sentido da passagem (exemplos 1, 3, 5 e 7), ou de pequenas omissões e interpolações (em 2, 4 e 6). A glosa interpolada pelo copista no exemplo 6 consiste provavelmente numa fórmula então corrente de juramento, que o amanuense registra recorrendo a um símbolo abreviador (“à fe e por esta †").

Tabela 3.4: Erros do códice D.

\begin{tabular}{|c|c|l|l|}
\hline No. & Localiz. & \multicolumn{1}{|c|}{ D } & \multicolumn{1}{c|}{ A, B, C, E, F, G } \\
\hline 1 & Cap. 01 & por que elle com cruz̧idade, em que vivia & por que elle com a Occiozidade, em que vivia \\
\hline 2 & Cap. 01 & $\begin{array}{l}\text { nem elle teve trabalho, n? os deu a seus } \\
\text { povos }\end{array}$ & $\begin{array}{l}\text { nem elle teve trabalho, n? o deu a seus } \\
\text { povos }\end{array}$ \\
\hline 3 & Cap. 12 & porque juntas tantas à tardança & porque juntastes à tardança \\
\hline 4 & Cap. 59 & e ella menos de que se honrar & e ella menos de que se correr \\
\hline 5 & Cap. 60 & Eu senhor cavalleyro & Eu senhor sou cavalleyro \\
\hline 6 & Cap. 61 & Via o outro perigo de primor & Via o outro prodigio de primor \\
\hline 7 & Cap. 64 & suprireis com calidade os deffeitos & suprireis com charidade os deffeitos \\
\hline 8 & Cap. 80 & $\begin{array}{l}\text { nem quando o não fizesse para de qu? } \\
\text { elle tivesse muita satisfação }\end{array}$ & $\begin{array}{l}\text { nem quando o não fizesse pessoa, de qu? elle } \\
\text { tivesse muita satisfação }\end{array}$ \\
\hline
\end{tabular}

O manuscrito $\mathrm{D}$ apresenta também mais erros que C. São várias as trocas de palavras que prejudicam a compreensão da frase (como em 1, 3, 4, 6, 7 e 8), devido a falhas de leitura ou erros mecânicos de transcrição. Não faltam erros de concordância, como o verificado no exemplo 2. Em 5 omitiu-se o verbo "sou", sem o qual a frase perde o sentido.

Em suma, o breve exame realizado é suficiente para atestar a superioridade da lição de $\mathrm{C}$ em comparação com a de $\mathrm{D}$. Vejamos agora os pontos de contato entre os dois manuscritos. 
Tabela 3.5: Variantes comuns a C e D.

\begin{tabular}{|c|c|c|c|c|}
\hline $\mathbf{N}^{\circ}$ & Localiz. & C & D & $\mathrm{A}, \mathrm{B}, \mathrm{E}, \mathrm{F}, \mathrm{G}$ \\
\hline 1 & Cap. 01 & $\begin{array}{l}\text { a qual hia crescendo em } \\
\text { fermozura, e boas partes } \\
\text { outras de maneira, que }\end{array}$ & $\begin{array}{l}\text { a qual hia crescendo em } \\
\text { fermozura, e boas partes } \\
\text { outras de maneira, que }\end{array}$ & $\begin{array}{l}\text { a qual hia crescendo em } \\
\text { fermozura, e boas partes de } \\
\text { maneira, que }\end{array}$ \\
\hline 2 & Cap. 11 & $\begin{array}{l}\text { delphins, que atopondoce a } \\
\text { Ella }\end{array}$ & $\begin{array}{l}\text { delphins, que trepandoce a } \\
\text { ella }\end{array}$ & delphis, que sotopondoce a ella \\
\hline 3 & Cap. 11 & $\begin{array}{l}\text { mas ja quando chegarão } \\
\text { áquellas Princezas, (que } \\
\text { de todo se tinhão } \\
\text { contado por acabadas } \\
\text { quando virão lançar a } \\
\text { Ponte, e desmaiadas } \\
\text { todas estavão esperando } \\
\text { o que a fortuna quereria } \\
\text { dispor dellas) acharão } \\
\text { que tornadas em seu } \\
\text { acordo }\end{array}$ & $\begin{array}{l}\text { mas ja quando chegarão } \\
\text { áquellas Princezas, (que de } \\
\text { todo se tinhão contado por } \\
\text { acabadas quando virão } \\
\text { lançar a Ponte, e desmaiadas } \\
\text { todas estavão esperando o } \\
\text { que a fortuna quereria dispor } \\
\text { dellas), e tanto que tornarão em } \\
\text { seu acordo }\end{array}$ & $\begin{array}{l}\text { mas ja quando chegarão } \\
\text { áquellas Princezas, (que de } \\
\text { todo se tinhão contado por } \\
\text { acabadas quando virão lançar } \\
\text { a Ponte, e desmaiadas todas } \\
\text { estavão esperando o que a } \\
\text { fortuna queria dispor dellas) } \\
\text { acharão que tornadas em seu } \\
\text { acordo }\end{array}$ \\
\hline 4 & Cap. 59 & esperar hu largo termo & esperar hu largo termo & esperar hu largo tempo \\
\hline 5 & Cap. 60 & $\begin{array}{l}\text { parecevos que ficava } \\
\text { retirada algua a hu homem } \\
\text { que nem be de pedra, nem } \\
\text { nasceu de pedras? parecevos } \\
\text { que podia eu deixar de } \\
\text { seguir a Daraja os passos } \\
\text { por onde me ella } \\
\text { encaminhava? parecevos } \\
\text { que podia eu deixar de crer } \\
\text { hua Mulher não obrigada a } \\
\text { the então mais }\end{array}$ & $\begin{array}{l}\text { parecevos que ficava retirada } \\
\text { algua a hu homem que não he } \\
\text { de pedra nem nasceu de pedras? } \\
\text { parecevos que podia eu deixar } \\
\text { de seguir a Daraja os passos } \\
\text { por onde ella me encaminhava? } \\
\text { parecevos que podia eu deixar } \\
\text { de querer hua Mulher não } \\
\text { obrigada a the então mais }\end{array}$ & $\begin{array}{l}\text { parecevos que ficava retirada } \\
\text { algua a hu homem que não he de } \\
\text { pedra, nem dellas nasceu (E/F: que } \\
\text { nem he de pedra nem nasceu de } \\
\text { pedra)? parecevos que podia eu } \\
\text { deixar de seguir a Daraja os } \\
\text { (E/F: pellos) passos por onde me } \\
\text { ella encaminhava? parecevos } \\
\text { que podia eu deixar de crer } \\
\text { (querer em E/F) hua Mulher } \\
\text { não obrigada (que não obrigava em } \\
\text { E/F) a the então mais }\end{array}$ \\
\hline
\end{tabular}

Embora poucos, os exemplos acima podem sugerir a existência de certo grau de afinidade entre C e D. Em 2, as lições dos manuscritos em questão são divergentes entre si, mas podem indicar que ambos sejam provenientes de um ramo da tradição em que a passagem apresentava algum tipo de corrupção ou dificuldade de leitura, pelo que os copistas de C e D a emendaram, cada um à sua maneira. Em 1 e 4, as variantes apresentadas são pouco significativas e são comuns também ao manuscrito G. Os exemplos 3 e 5 estão situados em pontos críticos do texto, em que há grande quantidade de variantes em todos os códices. ${ }^{27}$ No exemplo 3, importa notar que C e D são os únicos a trazer

27 Na passagem correspondente ao exemplo 3, os manuscritos E e F apresentam erros que tornam a frase incompreensível: "quando chegarão aquelles principes que tudo (F: todo) se tinha contado por acabadas". Também o códice B apresenta problemas nesta passagem: é omitido o verbo "chegarão" e, ao final, a palavra "tornadas" é substituída por "todas", o 
"quereria", ao invés de "queria"; quanto ao uso de "tornarão" em D, trata-se de uma variante que não prejudica o sentido da frase. No exemplo 5, as lições de $\mathrm{C}$ e $\mathrm{D}$ apresentam algumas variantes únicas e outras que os aproximam ora de um ora de outro dos ramos já descritos; quanto à variação crer/querer, $\mathrm{C}$ aproxima-se do ramo $\mathrm{A} / \mathrm{B}$, ao passo que $\mathrm{D}$ apresenta a mesma lição de $\mathrm{E} / \mathrm{F}^{28}$ Em suma, embora bastante frágeis, os indícios da existência de alguma ligação entre C e D não devem ser negligenciados.

Quanto à relação dos manuscritos $\mathrm{C}$ e $\mathrm{D}$ com os outros ramos da tradição, verifica-se mais uma vez que a lição de $\mathrm{C}$ em algumas passagens coincide com a de A/B, como sugere um dos exemplos da tabela acima (5). Os outros casos de concordância encontrados são os seguintes:

Tabela 3.6: Variantes comuns a A/B e C.

\begin{tabular}{|c|c|c|c|}
\hline No. & Localiz. & A/B e $C$ & $\mathrm{D}, \mathrm{E}, \mathrm{F}, \mathrm{G}$ \\
\hline 1 & Cap. 11 & $\begin{array}{l}\text { do Arco de Iris, (a que vulgarmente } \\
\text { chamamos arco da velha) }\end{array}$ & $\begin{array}{l}\text { do Arco de Iris, (a que vulgarmente chamamos da } \\
\text { velha) }\end{array}$ \\
\hline 2 & Cap. 59 & $\begin{array}{l}\text { Com menos ira se costumão receber os } \\
\text { hospedes }\end{array}$ & Com menos ira se costuma receber os hospedes \\
\hline 3 & Cap. 60 & estais de todo entregue a não crer nada & estais de todo entregue a não querer nada \\
\hline 4 & Cap. 62 & $\begin{array}{l}\text { começarão hua assas notavel e perigoza } \\
\text { batalha }\end{array}$ & começarão hua assas notavel batalha \\
\hline $5^{*}$ & Cap. 80 & jornada à quelle Reyno & jornada à quelles Reynos \\
\hline
\end{tabular}

A maior parte dos exemplos em que a lição de $C$ diverge da de $\mathrm{D}$ e concorda com a do ramo A/B são, como se pode ver acima, pouco significativos. ${ }^{29}$ Em 1, há uma interpolação do termo "arco", que estava subentendido; no exemplo 2 a mudança limita-se à conjugação verbal, sem acarretar erro; em 5 a variação entre plural e singular é pouco relevante: digna de nota é apenas a circunstância de o trecho ter sido copiado pelo segundo punho do códice C.

que também prejudica a compreensão deste trecho. São dados que só fazem reforçar as conclusões relativas aos ramos A/B e E/F expostas anteriormente. Quanto ao ex. 5, além das numerosas variantes já apontadas no quadro, falta notar que o copista de B atrapalhou-se com as diversas repetições da frase, apresentando uma lição confusa.

28 A passagem em questão não consta do manuscrito $G$, pois, como veremos adiante, esse códice apresenta uma lacuna que abrange todo o capítulo 60.

29 Aos casos apresentados na tabela 3.6, devem ser somados dois já comentados anteriormente: tabela 3.2 (ex. 3) e tabela 3.5 (ex. 5). 
A passagem reproduzida no exemplo 4 é das que mais apresentam variantes nas diferentes cópias: além das lições reproduzidas acima, em D lê-se "hia lastimoza e perigoza batalha" e G apresenta "hia notavel e perigoza batalha" (omitindo a palavra "assas"). O caso mais significativo é o do exemplo 3, em que $\mathrm{A} / \mathrm{B}$ e C trazem "crer" onde todos os demais testemunhos apresentam "querer". Dado que a variação é exatamente igual à verificada no exemplo 5 da tabela anterior, não seria razoável atribuir a coincidência apenas ao acaso.

Entretanto, as concordâncias descobertas entre as lições de C e A/B não são suficientemente numerosas para fundamentar hipóteses seguras acerca de possíveis pontos de contato entre os manuscritos em zonas mais altas da tradição. $\mathrm{O}$ exame das concordâncias sugere, inclusive, que em alguns casos elas podem ser fruto de meras coincidências (principalmente nos exemplos 1, 2 e 5$)$.

Menos numerosas e mais inconsistentes ainda são as coincidências encontradas entre os manuscritos C ou D e os outros códices (E, F e G). Devido à enorme quantidade de variantes existentes nos manuscritos, seria possível elaborar listas de concordâncias entre todos os testemunhos; na maioria dos casos, entretanto, as ocorrências devem ser caracterizadas como simples lições adiáforas ou erros poligenéticos, isto é, provavelmente introduzidos em ramos independentes da tradição, casualmente equivalentes e por isso mesmo pouco significativos.

Em síntese, os elementos colhidos na colação não permitem inferir conclusões definitivas a respeito dos manuscritos $\mathrm{C}$ e D. Embora haja indícios da existência de certo grau de parentesco entre eles, sua afinidade está longe de ser vinculante como a verificada entre $\mathrm{A}$ e $\mathrm{B}$ ou $\mathrm{E}$ e $\mathrm{F}$ - pelo que não os consideramos representantes de um novo ramo da tradição manuscrita da Crônica de D. Duardos I. Cópias independentes, de qualidade desigual (pois, como já foi dito, a lição de C é mais próxima da dos demais testemunhos, apresentando menos variantes e erros), os manuscritos $\mathrm{C}$ e $\mathrm{D}$ ocupam posição intermediária em relação aos ramos descritos anteriormente, visto que ora se aproximam do ramo $\mathrm{A} / \mathrm{B}$ (nos casos em que $\mathrm{E}$ e $\mathrm{F}$ apresentam variantes que lhes são exclusivas: cf. tabelas 2.1 a 2.3), ora concordam com E/F (nas passagens em que há variantes caracterizadoras do parentesco entre A e B: cf. tabelas 1.1 a 1.5$)$.

Com base nas informações disponíveis, contudo, é impossível precisar com segurança a posição dos códices $\mathrm{C}$ e $\mathrm{D}$ na tradição manuscrita. Admitimos provisoriamente a hipótese de ambos derivarem direta ou indiretamente de um subarquétipo comum, hoje perdido, como sugerem os exemplos da tabela 3.5, apesar de estarmos conscientes da fragilidade de tais indícios. A 
maior proximidade de $\mathrm{C}$ com relação ao ramo A/B (para a qual parecem apontar os igualmente frágeis exemplos da tabela 3.6, em especial o exemplo 3), entretanto, levanta problemas cuja solução exigiria a colação de outros trechos da Crônica. Duas são as suposições plausíveis: a) essa afinidade deve-se a parentesco mais distante, num hipotético nível intermediário situado em área mais alta da tradição; ou b) ela é resultado de uma contaminação. Por ora, na falta de mais elementos, restringimo-nos a propor uma solução conjectural, que atenda aos critérios de simplicidade e de economia quanto à suposição da existência de testemunhos intermediários perdidos. A linha segmentada representa um possível caso de contaminação. ${ }^{30}$

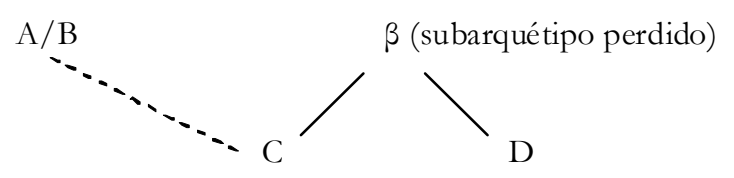

\subsection{Códice G}

O códice BNL 619 (G) é o que mais se diferencia dos restantes testemunhos. Único manuscrito a ser redigido em duas colunas, apresenta texto bem legível, mas repleto de erros e variantes - tantas e tão significativas, que o situam em posição à parte na tradição manuscrita.

A primeira que salta aos olhos é relativa à discrepância do número de capítulos desse códice em comparação com as outras cópias conhecidas do texto: com efeito, se em todos os outros testemunhos a Crônica de D. Duardos I possui 80 capítulos, em $\mathrm{G}$ ela é composta por apenas $74 .{ }^{31} \mathrm{Da}$ comparação entre os títulos, as frases iniciais e finais dos capítulos dos códices A e G, pudemos concluir pela existência de quatro zonas em que a matéria narrativa é submetida a subdivisões discrepantes: entre os capítulos 10-18, 22-23, 26-30 e 59-61 da versão do manuscrito A. ${ }^{32}$ Em alguns casos, a matéria de um único

30 A existência de um antecedente comum a $\mathrm{C}$ e o ramo A/B aparentemente contradiz a hipótese de $\mathrm{C}$ e $\mathrm{D}$ derivarem de um subarquétipo comum, tendo em vista a falta de elementos comprobatórios da proximidade entre as lições de A/B e D. Além disso, a especulação sobre o suposto codex interpositus criaria dificuldades para explicar as concordâncias existentes entre C e D e o ramo E/F, que são relevantes (cf. tabelas 1.1 a 1.5).

31 Embora a numeração prossiga até o número 76, o texto apresenta apenas 74 capítulos, visto que o códice não possui os capítulos 56 e 57.

32 Tomamos a lição de A como representativa dos capituleiros dos demais testemunhos, pois eles não apresentam variantes significativas entre si, conforme atesta também Palma-Ferreira, 1983, 
capítulo de A foi distribuída por dois capítulos em G (como ocorre com o capítulo 10, que corresponde grosso modo aos capítulos 10 e 11 de G); em outros casos verifica-se o contrário, isto é, que a matéria de um único capítulo de $\mathrm{G}$ corresponde à de dois ou mais capítulos de $\mathrm{A}$ (é o caso dos capítulos 11 e 12 de A, que foram condensados no capítulo 12 de G). A tabela abaixo apresenta a correspondência entre os capítulos dos dois códices. As zonas em que há divergências foram assinaladas com asterisco.

Tabela 4.1: Capituleiros de A e G.

\begin{tabular}{|l|l|}
\hline \multicolumn{1}{|c|}{ A } & G \\
\hline Capítulos 1-9 & Capítulos 1-9 \\
\hline$*$ Capítulo 10 & $*$ Capítulos 10-11 \\
\hline$*$ Capítulos 11-12 & $*$ Capítulo 12 \\
\hline$*$ Capítulos 13-14 & $*$ Capítulo 13 14 \\
\hline$*$ Capítulos 15-16 & $*$ Capítulo 15 \\
\hline$*$ Capítulos 17-18 & Capítulos 16-18 \\
\hline Capítulos 19-21 & $*$ Capítulos 19-21 \\
\hline$*$ Capítulos 22-23 & Capítulos 22-23 \\
\hline Capítulos 24-25 & $*$ Capítulos 24-26 \\
\hline$*$ Capítulos 26-30 & Capítulos 27-54 \\
\hline Capítulos 31-58 & $*$ Capítulo 55 \\
\hline * Capítulos 59-61 & \\
\hline Capítulos 62-80 & \\
\hline
\end{tabular}

Além das diferenças apontadas na tabela, há outras. Em G, os capítulos $18,20,21,23,25$ e 26 não apresentam título, embora o copista tenha deixado o espaço reservado para anotá-lo. No caso do capítulo 17, o título foi acrescentado posteriormente, por outra mão.

A maior anomalia do texto parece ser a do capítulo 55 de G (= capítulos 59 a 61 de A). Ali, não ocorre apenas a reunião de três capítulos em um só;

p. 9-33. A identificação destas zonas discrepantes foi utilizada como critério para definir quais trechos da obra seriam submetidos à colação, conforme declaramos anteriormente (cf. o início do item 2). 
na realidade, a versão de $G$ apresenta uma lacuna de porção significativa do trecho correspondente nos demais manuscritos. Dado que a falha, como veremos, provavelmente remonta ao antecedente de $G$, fato que o copista não notou, une-se uma frase da metade do capítulo 59 de A a outra do meio do capítulo 61, sem qualquer anotação, o que resulta numa lição incompreensível, conforme se pode verificar na tabela abaixo. ${ }^{33}$

Tabela 4.2: Lacuna em G (caps. 59-61).

\begin{tabular}{|c|c|c|c|}
\hline Local. & G & Local. & $\mathrm{A}, \mathrm{B}, \mathrm{C}, \mathrm{D}, \mathrm{E}, \mathrm{F}$ \\
\hline \multirow[t]{2}{*}{ Cap. 55} & \multirow{2}{*}{$\begin{array}{l}\text { fazen } \mid \text { do mais concideração não | o } \\
\text { tinha por couza facil, porque | se os } \\
\text { hom?ns erão honrrados co } \mid \text { mo a } \\
\text { elle lhe parecião perdia | mais em faze- } \\
\text { las, que em obser } \mid \text { va-las e a razão era que } \\
\text { andar | perderia o que desencarregan } \mid \text { do } \\
\text { a culpa a quem naquelles | cazos a tem } \\
\text { sempre que são a }|| \text { col. b]quellas } \\
\text { violencias gran } \mid \text { des, com que o amor cega o } \\
\mid \text { Entendimento }\end{array}$} & $\begin{array}{c}\text { Cap. } \\
59\end{array}$ & $\begin{array}{l}\text { fazendo mais concideração não o tinha por } \\
\text { couza facil, porque se os hom?ns erão } \\
\text { honrados como lhe a elle parecião, quando não } \\
\text { tivess? força para se deffender, terião animo para não } \\
\text { confessar, e se o não fossem em remettendo a elles the } \\
\text { fogirião... }\end{array}$ \\
\hline & & $\begin{array}{c}\text { Cap. } \\
61\end{array}$ & $\begin{array}{l}\text { mais tinha de que se contentar na quebra daquellas } \\
\text { promessas, que no comprimento dellas como ella } \\
\text { perdia mais em fazellas e cumprillas, do que } \\
\text { em observallas, e a razão era que em dar } \\
\text { perderia o desse carregando a culpa, aqu? na } \\
\text { quelles cazos a tem sempre, que são aquellas } \\
\text { violencias grandes, com que o amor cega o } \\
\text { Entendimento }\end{array}$ \\
\hline
\end{tabular}

Além disso, o capítulo seguinte em $G$ recebeu o número 58, e não 56 como seria de esperar, o que reforça a hipótese de que a lacuna remonta ao antígrafo de G. Tal lacuna abrangeria o final do capítulo 55 (=59 de A), o capítulo 56 inteiro (=60 de A) e a porção inicial do capítulo 57 (=61 de A). Assim, explica-se também o motivo de o salto na numeração dos capítulos de $G$ não corresponder a nova lacuna do texto.

Se é verdade que as anomalias do capítulo 55 de G são explicáveis pela perda de alguns fols. em seu antecedente, conclui-se que as zonas do texto em que o copista de $G$ (ou de seu antecedente) o submeteu a novo arranjo dos capítulos restringe-se ao primeiro terço do livro - ou, mais precisamente, entre os capítulos 10 e 30 da versão de A, conforme é possível verificar pela

33 O salto ocorre no f. $147 \mathrm{v}$, col. a de G. Na tabela a seguir, são destacadas as divisões de linhas do manuscrito $G$, de modo que é possível verificar que a união dos trechos pertencentes aos capítulos 59 e 61 das outras cópias de fato ocorre numa mesma linha de G, sem qualquer anotação por parte do copista. No quadro em que se apresenta o texto de $G$, a parte correspondente ao capítulo 61 está em itálico; nos quadros com o texto dos outros testemunhos, estão em itálico o início e o final do trecho omitido em G. 
tabela 4.1. E, com efeito, dentre os capítulos examinados na colação, foram nos de número 11 e 12 que encontramos as maiores discrepâncias entre a versão de $G$ e a lição dos outros manuscritos. ${ }^{34}$ Por isso, as variantes de $G$ nesses capítulos serão examinadas à parte.

Vejamos primeiramente alguns exemplos das numerosas lições adiáforas que $\mathrm{G}$ apresenta fora da área em que há divergências quanto à estrutura dos capítulos (ou seja, nos capítulos 01, 59-62, 64 e 80).

Tabela 4.3: Lições adiáforas de G.

\begin{tabular}{|c|c|l|l|}
\hline No. & Localiz. & \multicolumn{1}{|c|}{ G } & \multicolumn{1}{|c|}{ A, B, C, D, E, F } \\
\hline 1 & Cap. 01 & $\begin{array}{l}\text { Mandando embaixadores } \\
\text { frequentes }\end{array}$ & Mandando embaxadas frequentes \\
\hline 2 & Cap. 59 & $\begin{array}{l}\text { Bem empregado serà tudo pois } \\
\text { vos por teima (respondeu o } \\
\text { companheiro), não quizestes } \\
\text { esperar }\end{array}$ & $\begin{array}{l}\text { Bem empregado serà tudo (respondeu } \\
\text { quizestes esperar }\end{array}$ \\
\hline 3 & Cap. 59 & $\begin{array}{l}\text { forão para onde estava Trineo } \\
\text { forão indireitando para onde estava } \\
\text { Trineo }\end{array}$ \\
\hline 5 & Cap. 62 & paixão com que se combatião & paixão com que se accometião \\
\hline 5 & Não era passado muito da & Não era gastado muito da menhã \\
\hline
\end{tabular}

$\mathrm{Na}$ maior parte dos casos, as variantes são resultado da substituição de palavras por termos sinônimos ou próximos, sem prejuízo da inteligibilidade da frase, como nos exemplos 1, 4 e 5. Omissões ou interpolações de palavras não essenciais também são comuns, como no exemplo 3. Por fim, a ordem das palavras na frase foi alterada em 2 .

34 Note-se que, conforme foi dito anteriormente, os capítulos cotejados foram os de número $01,11,12,59-62,64$ e 80. Excluídos os capítulos 59-62 da zona em que a versão de $G$ distribui a matéria narrativa a outra divisão, restam apenas os capítulos 11-12. 
Tabela 4.4: Erros de G.

\begin{tabular}{|c|c|c|c|}
\hline No. & Localiz. & \multicolumn{1}{|c|}{ G } & \multicolumn{1}{|c|}{ A, B, C, D, E, F } \\
\hline 1 & Cap. 01 & $\begin{array}{l}\text { posto que em alguns podião } \\
\text { menos as saudades, que nos } \\
\text { outros, mais que Palmeirim, } \\
\text { Floriano, e os mais }\end{array}$ & $\begin{array}{l}\text { posto que em alguns podião menos as } \\
\text { saudades, que nos outros, porque } \\
\text { Palmeirim, Floriano, es mais }\end{array}$ \\
\hline 2 & Cap. 01 & vendo que os moços desobedecião já & vendo que os moços obedecião já \\
\hline 3 & Cap. 61 & $\begin{array}{l}\text { campo sanguinho e nas de Midas } \\
\text { campo sanguinho o jugo e Nós de Midas }\end{array}$ \\
\hline 5 & Cap. 62 & $\begin{array}{l}\text { tempo que as memorias da } \\
\text { senhora Fidellia me deixarem devir }\end{array}$ & $\begin{array}{l}\text { tempo que as memorias da senhora } \\
\text { Fidellia me deixarem de vida }\end{array}$ \\
\hline 6 & Cap. 64 & $\begin{array}{l}\text { mas custandolhes a elles seus } \\
\text { revezes }\end{array}$ & por dizero que sentia a Princeza \\
\hline
\end{tabular}

Quanto aos erros identificados em $G$, são de tipos semelhantes aos encontrados nos outros manuscritos. Vários são os casos de troca de palavras, prejudicando o sentido da frase, motivados seja por associações mentais (como parece ser o caso de 1) ou por erros de leitura (provavelmente em 2, 3 e 4). No exemplo 6 , a troca entre o singular e o plural compromete a inteligibilidade do trecho. Em 5 o erro se deve a uma pequena omissão.

Como dissemos, é nos capítulos 11 e 12 (=12 em G) que se concentra a maior quantidade de variantes significativas encontradas na colação. Apresentamos abaixo o confronto entre algumas das passagens desses capítulos em que a lição de $G$ mais se distancia das dos demais testemunhos. Além disso, constam da tabela também os trechos iniciais e finais dos capítulos, comprovando que o capítulo 12 de G corresponde exatamente aos capítulos 11 e 12 dos outros manuscritos. ${ }^{35}$

35 Alguns dos exemplos da tabela 4.5 compreendem trechos que já foram utilizados em exemplos de tabelas anteriores, como é o caso de 3 (em parte na tabela 1.5, ex. 2 e por outra parte na tabela 1.9, ex. 1), 4 (tabela 3.6, ex. 1) e 6 (tabela 1.7, ex. 1); em todos, desconsideramos aqui as diferenças então apontadas entre os manuscritos agora agrupados. 
Tabela 4.5: Variantes nos capítulos 11 e 12 (=12 de G).

\begin{tabular}{|c|c|c|c|}
\hline No. & Localiz. & G & $\mathrm{A}, \mathrm{B}, \mathrm{C}, \mathrm{D}, \mathrm{E}, \mathrm{F}$ \\
\hline 1 & $\begin{array}{l}\text { Cap. } 11 \\
\text { (início) }\end{array}$ & $\begin{array}{l}\text { Quatro dias antes das festas do } \\
\text { Spirito Sancto, que era o em que } \\
\text { havia cellebrar-se aquelle torneio }\end{array}$ & $\begin{array}{l}\text { Quatro dias antes da festa do Spirito } \\
\text { Sancto, que era } a \text { em que se havia de } \\
\text { celebraraquelle torneio }\end{array}$ \\
\hline 2 & Cap. 11 & $\begin{array}{l}\text { estando ja Floriano } e \text { Floris sãos de } \\
\text { suas feridas e Dramuqiando da sua } \\
\text { perna }\end{array}$ & $\begin{array}{l}\text { estando ja Floriano, D. Floris } e \\
\text { Dramuziando, bem sãos de suas feridas, } e \\
\text { perna }\end{array}$ \\
\hline 3 & Cap. 11 & $\begin{array}{l}\text { se vio a quelle globo ser de hua } \\
\text { Maça cristalina e tão transparente } e \\
\text { divizava-se dentro delle hua caza } \\
\text { grande armada de borcados } \\
\text { cramezins que erão os que o fazião } \\
\text { parecer de fogo. E sentado em cadeira o } \\
\text { mesmo Daliarte, e Floramão com } \\
\text { todos aquelles Princepes armados } \\
\text { de armas brancas, sem elmos, } \\
\text { espadas, nem esporas, mas ainda se } \\
\text { divizavão mal nem se poderão conhecer } \\
\text { se ja todos não sospeitarão o que era. }\end{array}$ & $\begin{array}{l}\text { se vio que a Materia da quelle globo era hua } \\
\text { Maça cristalina tão transparente, que se } \\
\text { diwizava dentro delle hua caza grande } \\
\text { armada de borcados cramezins que o fazião } \\
\text { parecer de fogo. E sentados nella em cadeiras do } \\
\text { mesmo borcado Daliarte, e Floramão com } \\
\text { todos aquelles Princepes armados de } \\
\text { armas brancas, sem elmos, espadas, nem } \\
\text { esporas, mas não se vião mui distintamente } \\
\text { estas mindezas, nem elles poderão ser conbecidos, } \\
\text { se ja todos não sospeitarão que o erão. }\end{array}$ \\
\hline 4 & Cap. 11 & $\begin{array}{l}\text { se foi levantando pouco a pouco } \\
\text { hua pyramide oitavada, e } \\
\text { composta de muitas cores, } \\
\text { semelhantes às que se vêm nas nuvens } \\
\text { ao pordo Sol nas tardes do verão }\end{array}$ & $\begin{array}{l}\text { se foi levantando pouco a pouco hua } \\
\text { como pyramide oitavada, composta de } \\
\text { varias cores, em materia não conbecida, } \\
\text { semelhantes entre si as do Arco de Iris, (a } \\
\text { que vulgarmente chamamos arco da velha) }\end{array}$ \\
\hline 5 & Caps. $11-12$ & $\begin{array}{l}\text { posto de giolhos diante delles, } \\
\text { tendo tirado o elmo ja quando } \\
\text { entrara na torre, e dice: Bem sei } \\
\text { que eide ser perdoado }\end{array}$ & $\begin{array}{l}\text { posto de giolhos diante delle tendo } \\
\text { tirado o elmo ja quando entrara na torre } \\
\text { e dicelhes o que no outro capitulo se segue. // } \\
\text { [cap. 12] Posto de giolhos Daliarte, como no } \\
\text { capitulo passado diziamos, diante de seu Pay, e } \\
\text { daquelles Princepes, que pella varanda vinhão, } \\
\text { dicelhes: Bem sei que eide ser perdoado }\end{array}$ \\
\hline 6 & $\begin{array}{l}\text { Cap. } 12 \\
\text { (fim) }\end{array}$ & $\begin{array}{l}\text { forão todos assi como vinhão á } \\
\text { capella do Emperador a velar as } \\
\text { armas, aonde as mais da quellas } \\
\text { senhoras cazadas os } \\
\text { acompanharão, athe o outro dia, } \\
\text { no qual forão armados do modo que } \\
\text { no capitulo seguinte Mostraremos. }\end{array}$ & $\begin{array}{l}\text { forão todos assi como vinhão á capella, } \\
\text { que nos Paços estava a velar as armas, onde } \\
\text { as mais da quellas senhoras cazadas os } \\
\text { acompanharão athe o outro dia, no qual } \\
\text { forão armados cavalleiros, como no } \\
\text { capitulo seguinte Mostraremos. }\end{array}$ \\
\hline
\end{tabular}

De modo geral, nota-se a tendência ligeiramente mais sintética da lição de $G$ em comparação com a dos outros códices: são eliminados alguns detalhes (como nos exemplos 3 e 6 ) ou realizadas alterações simplificadoras na redação de certos trechos (2 e 4). Em ao menos um caso, a versão de G supera em clareza a das outras cópias (2). A mudança de capítulo foi assinalada em 5 com dois traços oblíquos; o título do novo capítulo em A não foi reproduzi- 
do, a fim de facilitar a identificação das adaptações realizadas pelo copista de G (ou de seu antígrafo) na junção dos caps. 11 e 12.

Em relação aos ramos e aos outros códices descritos, a lição dos capítulos 11 e 12 de $G$ não possui semelhanças significativas. O confronto com algumas das variantes caracterizadoras do ramo $\mathrm{A} / \mathrm{B}$ demonstra que nestas passagens a lição de $\mathrm{G}$ concorda com a de $\mathrm{C}, \mathrm{D}$ e E/F, conforme é possível verificar pelos exemplos abaixo: ${ }^{36}$

Tabela 4.6: Capítulos 11 e 12 (= 12 de G): contraste entre G e A/B.

\begin{tabular}{|c|c|c|c|c|}
\hline $\mathbf{N}^{\mathbf{0}}$ & Localiz. & \multicolumn{2}{|c|}{ G } & \multicolumn{1}{|c|}{$\mathbf{\text { A/B }}$ D, E, F } \\
\hline 1 & Cap. 11 & $\begin{array}{l}\text { como se se temerão de } \\
\text { males grandes }\end{array}$ & $\begin{array}{l}\text { como se se temerão de } \\
\text { grandes males }\end{array}$ & $\begin{array}{l}\text { como se se temerão de males } \\
\text { grandes }\end{array}$ \\
\hline 2 & Cap. 12 & $\begin{array}{l}\text { tornou a dizer para } \\
\text { Daliarte. Por certo senhor } \\
\text { Daliante que não sei }\end{array}$ & $\begin{array}{l}\text { tornou a dizer para } \\
\text { Daliarte: Que não sei }\end{array}$ & $\begin{array}{l}\text { tornou a dizer para Daliarte, } \\
\text { por certo senhor Daliarte que não } \\
\text { sei }\end{array}$ \\
\hline 3 & Cap.12 & $\begin{array}{l}\text { obedecendo à força } \\
\text { interior, com que } \\
\text { Daliarte os obrigava }\end{array}$ & $\begin{array}{l}\text { obedecendo à força superior } \\
\text { interior, com que Daliarte } \\
\text { os obrigara }\end{array}$ & $\begin{array}{l}\text { obedecendo à força interior, } \\
\text { com que Daliarte os obrigava }\end{array}$ \\
\hline
\end{tabular}

A lição de $G$ não partilha a inversão da ordem das palavras (exemplo 1), nem da interpolação e da alternância entre $\mathrm{r} / \mathrm{v}$ (em 3) que caracterizam a lição de A e B. A pequena lacuna do texto na lição do ramo A/B também não é reproduzida em $\mathrm{G}$ (ex. 2), o que significa que nenhum daqueles códices pode ter sido o antígrafo de $G$ ou de seu antecedente.

Com relação aos manuscritos $\mathrm{C}$ e $\mathrm{D}$, raras foram as variantes exclusivas desses códices nos capítulos 11 e 12 que permitiram o confronto com a lição de G. Afora os casos pouco significativos de erros exclusivos a $\mathrm{C}$ ou $\mathrm{D}$, que nunca são reproduzidos em $\mathrm{G}$, resta apenas um exemplo (tabela 3.5, ex. 3). Nessa passagem, reproduzida abaixo, a lição de $\mathrm{G}$ não concorda com a de $\mathrm{C}$ e D.

36 Alguns foram comentados anteriormente: cf. tabela 1.2 (ex. 2); tabela 1.5 (ex. 3) e tabela 1.4 (ex. 1). Posto que a lição de G nos capítulos 11 e 12 diverge bastante das demais, nem todas as variantes caracterizadoras dos ramos anteriores possuem correspondência precisa em G. 
Tabela 4.7: Capítulos 11 e 12 (= 12 de G): contraste entre $\mathrm{G}$ e os manuscritos $\mathrm{C}$ e $\mathrm{D}$.

\begin{tabular}{|c|c|c|c|c|}
\hline $\mathbf{N}^{\circ}$ & Localiz. & G & C e D & $\mathrm{A}, \mathrm{B}, \mathrm{E}, \mathrm{F}$ \\
\hline 1 & Cap. 11 & $\begin{array}{l}\text { o que a fortuna queria } \\
\text { dispor dellas }\end{array}$ & $\begin{array}{l}\text { o que a fortuna quereria } \\
\text { dispor dellas }\end{array}$ & $\begin{array}{l}\text { o que a fortuna queria } \\
\text { dispor dellas }\end{array}$ \\
\hline
\end{tabular}

Com a quase totalidade das variantes caracterizadoras do ramo $\mathrm{E} / \mathrm{F}$ verifica-se o mesmo: ${ }^{37}$

Tabela 4.8: Capítulos 11 e 12 (= 12 de G): contraste entre G e E/F.

\begin{tabular}{|c|c|c|c|c|}
\hline $\mathbf{N}^{\circ}$ & Localiz. & G & $E / F$ & $A, B, C, D$ \\
\hline 1 & Cap. 11 & $\begin{array}{l}\text { aquelle tão extraordinario } \\
\text { incêndio }\end{array}$ & $\begin{array}{l}\text { aquelle extraordinario } \\
\text { incêndio }\end{array}$ & $\begin{array}{l}\text { aquelle tão extraordinario } \\
\text { incendio }\end{array}$ \\
\hline 2 & Cap. 11 & onde a cerpe se sumira & onde a serpente se sumira & onde a serpente se sumengira \\
\hline 3 & Cap. 12 & $\begin{array}{l}\text { eu quis que estes Donzeis } \\
\text { viss? primeiro porque pois } \\
\text { tem todos bua mesma idade, } \\
\text { tw̃essem hua comversação. Este } \\
\text { he Dom Floris }\end{array}$ & $\begin{array}{l}\text { eu quis que estes Donzeis } \\
\text { viss? e conhecessem } \\
\text { primeiro que a nimgu? desta } \\
\text { terra, para que depois com } \\
\text { hua mesma idade ande correr } \\
\text { todos quazi bua mesma fortuna, } \\
\text { não hes faltasse este } \\
\text { conbecimento pois não pode } \\
\text { deixar de ser a criação este de } \\
\text { Dom Floris (F: este donzel } \\
\text { Flonis) }\end{array}$ & $\begin{array}{l}\text { eu quis que estes Donzeis viss? e } \\
\text { conhecessem primeiro que } \\
\text { animgu? desta terra, para que pois } \\
\text { com hua mesma idade ande correr } \\
\text { todos quazi hua mesma fortuna, não } \\
\text { lhes faltasse este conbecimento pois não } \\
\text { pode deixar de ser a criação. Este he } \\
\text { DomFloris }\end{array}$ \\
\hline 4 & Cap. 12 & $\begin{array}{l}\text { velassem as armas para que } \\
\text { a o outro dia o foss? }\end{array}$ & $\begin{array}{l}\text { velassem as armas para que } \\
\text { ao (F: o) foss? }\end{array}$ & $\begin{array}{l}\text { velassem armas para que } a \text { o outro } \\
\text { dia o foss? }\end{array}$ \\
\hline
\end{tabular}

A maioria das variantes caracterizadoras do ramo $\mathrm{E} / \mathrm{F}$ também não são partilhadas por $G$, que, nesses casos, aproxima-se mais do ramo $\mathrm{A} / \mathrm{B}$ e dos códices $\mathrm{C}$ e $\mathrm{D}$. No exemplo 3, em que é mais uma vez perceptível a tendência à síntese de $\mathrm{G}$, é importante notar que este manuscrito não apresenta o mesmo erro de E/F ao final do trecho ("este de Dom Floris" ou "este donzel Floris"), mas segue a lição dos outros testemunhos, que é mais clara. Da mesma forma, $G$ não apresenta as pequenas omissões dos códices $\mathrm{E}$ e F

37 Os exemplos abaixo também se encontram em tabelas anteriores, quando foram apresentadas as características do ramo E/F: cf. tabela 2.2 (ex. 2); tabela 2.1 (ex. 3); tabela 2.6 (exs. 1 e 2). 
nos exemplos 1 e 4, comprovando que nenhum deles pode ser considerado seu antecedente.

O caso do exemplo 2, no entanto, propõe novos problemas. A coincidência da substituição de "sumergira" por "sumira", que seria pouco provável em ramos independentes da tradição, pode indicar a existência de algum grau de parentesco entre G e o ramo E/F. Se, como dissemos acima, esses códices não podem ser antecedentes de $G$, a confluência entre eles só pode ser procurada em nível mais alto da tradição. A identificação precisa de tal ligação, contudo, demandaria o cotejo de outras partes do texto, pois a simples suposição de um antecedente comum entre $\mathrm{G}$ e o ramo $\mathrm{E} / \mathrm{F}$ não seria suficiente para justificar as numerosas diferenças entre eles, bem como os casos em que G partilha de lições comuns com os ramos A/B e com os códices C e D. ${ }^{38}$ Posto que, na falta de novas evidências, não há como avançar com segurança na especulação acerca de supostos intermediários perdidos, a questão terá de aguardar novos estudos para ser respondida.

Em suma, o exame do códice BNL 619 (G) revela que em tese ele apresentaria uma versão integral da Crônica de D. Duardos I, apesar da discrepância do número de capítulos que o compõem. A grande lacuna existente no capítulo 55 (= 59 a 61 dos outros testemunhos) não foi intencional, mas é resultado da provável perda de alguns fólios do manuscrito que serviu de base para a cópia (a que chamaremos ä), como dá a entender o salto na numeração dos capítulos em G. As informações de que dispomos não permitem dirimir, contudo, outras dúvidas: as discrepâncias quanto à estrutura dos capítulos já constavam de ä ou são de responsabilidade do copista de G? Por que foram introduzidas alterações tão significativas no texto: elas corresponderiam ao desejo do autor ou foram emendas feitas por um copista mais "rebelde"? Como explicar as convergências entre $\mathrm{G}$ e as demais cópias, raras em meio à quantidade de diferenças que o distanciam de todos os outros testemunhos? As perguntas só poderão ser respondidas com a colação de outros trechos da obra. Limitamo-nos por enquanto a indicar a existência do antecedente de $G$, cuja existência fica comprovada pelas reflexões anteriores, e a sugerir um possível caso de contaminação com o ramo E/F, de modo a justificar a coincidência registrada no ex. 2 da tabela 4.8.

38 As convergências de $\mathrm{G}$ com o ramo A/B em contraste com E/F são particularmente visíveis nas tabelas 2.1 a 2.3. Com relação às concordâncias com os códices $\mathrm{C}$ e $\mathrm{D}$, algumas já foram apontadas em observações anteriores, como, por exemplo, nos comentários à tabela 3.5 (exemplos 1 e 4). 


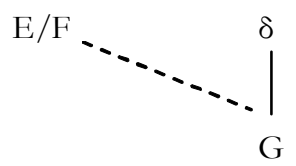

\section{A tradição manuscrita: conclusões}

Embora tenha fornecido elementos preciosos sobre a tradição manuscrita do texto, a colação dos códices da primeira parte da Crônica de D. Duardos não revelou dados suficientes para o desenho de um stemma codicum completo - o que não chega a surpreender, dada a extensão do texto e a quantidade de cópias. Algumas das hipóteses propostas ao longo do exame dos diferentes ramos da tradição manuscrita poderão ser verificadas em pesquisas futuras, caso outras partes do texto venham a ser cotejadas. Certas dúvidas, porém, talvez permaneçam sem resposta, a menos que sejam descobertas novas peças do quebra-cabeças; pois não é de todo impossível que ainda haja cópias da Crônica de D. Duardos esquecidas em bibliotecas ou coleções particulares. Com base nas informações disponíveis, por ora é possível apenas estabelecer com segurança o parentesco entre alguns testemunhos e conjecturar acerca de outros.

Dessa forma, o estema que vimos montando aos poucos nas últimas páginas representa um simples ponto de partida, uma primeira hipótese de trilha a seguir no labirinto da infinidade de variantes oferecidas por esses manuscritos até hoje praticamente intocados. Esperamos que nossas perplexidades e equívocos sirvam de convite para que outros pesquisadores alterem e aprofundem o que agora está apenas esboçado.

O estema aqui proposto pretende simplesmente indicar os vários ramos e grupos em que a tradição manuscrita da Crônica de D. Duardos I se subdivide. Quanto a possíveis intermediários desaparecidos, não arrisca conjecturas; alguns certamente terão existido, mas é impossível determinar por ora quantos e que posição deveriam ocupar no estema.

Estamos convencidos, entretanto, que tais intermediários não devem ter sido numerosos. Em primeiro lugar, porque a tradição textual portuguesa normalmente se apresenta "escassamente articulada e, muitas vezes, confiada a um único testemunho" - e quanto a essa tendência os textos dos séculos XVI e XVII não constituem exceção, de acordo com Giulia Lanciani (1986, p. 279). Assim, o fato de serem conhecidas hoje sete cópias da Crônica de D. Duardos I já configura um caso excepcional no panorama dos livros de mão em Portugal. Acresce a isso que, dentre os testemunhos remanescentes, cinco certamente não deixaram descendência conhecida (B, C, D, F e G) e apenas 
dois (os códices A e E) provavelmente tenham sido utilizados como base para a elaboração de novas cópias, o que parece indicar uma tradição pobre em níveis intermediários, em que a transmissão do texto ocorreu prioritariamente em sentido horizontal, a partir de um número reduzido de textos-base. ${ }^{39}$

Além disso, a aventura de imaginar códices perdidos e contaminações múltiplas entre os diversos manuscritos talvez não seja o único meio para explicar o intrincado cruzamento de convergências e discrepâncias das variantes que caracterizam os testemunhos conhecidos do livro. Sabe-se que nos séculos XVI e XVII é comum que o autor submeta sua obra a uma revisão mesmo depois que ela tenha começado a circular: é o caso de António Ribeiro Chiado, objeto do trabalho já citado de Giulia Lanciani. O fenômeno é tão freqüente no domínio da literatura portuguesa quinhentista que Spaggiari e Perugi, lembrando os exemplos de Camões, Sá de Miranda e António Ferreira, afirmam que "a filologia portuguesa da época renascentista é, na sua maioria, uma filologia de variantes autorais, distribuídas, muitas vezes, sob a forma de redações diferentes" (2004, p. 157). Assim, os diferentes ramos e grupos em que se divide a tradição da Crônica de D. Duardos I podem indicar não exatamente famílias de manuscritos, mas sim registros das diversas etapas de correção e revisão autoral do texto, o que explicaria a dificuldade de representar num estema único as múltiplas convergências de variantes que não parecem se distribuir de maneira homogênea entre os sete testemunhos remanescentes. $^{40}$

Trata-se, como é evidente, de mais uma hipótese a ser verificada em ulteriores aprofundamentos e pesquisas, caso outras partes do texto que venham a ser cotejadas confirmem as conclusões aqui expostas. Na elaboração do estema, contudo, utilizou-se o modelo convencional em que todos os testemunhos remontam a um único arquétipo, sem preocupação com a representação gráfica da possibilidade da existência de redações múltiplas.

De acordo com os dados revelados pela colação, em suma, o estema da tradição manuscrita do texto pode ser representado de duas formas ligeira-

39 O único intermediário perdido do qual há indícios de sua existência e que não consta do estema proposto é o antecedente de E, caso este códice tenha mesmo sido copiado do exemplar pertencente a D. Leonor Coutinho (cf. a descrição de E acima). Tal exclusão justifica-se pela natureza extratextual das evidências (que se baseiam em carta de D. Vasco Luiz da Gama, filho de D. Leonor, como vimos).

40 Giulia Lanciani observa que nos séculos. XVI e XVII “a tradição textual portuguesa é caracterizada (mais do que qualquer outra tradição européia) pela desenvolta moda das edições 'piratas' ou por uma tendência para as remodelações, ou ainda para os acréscimos subrepitícios: o que complica notavelmente o trabalho do editor crítico" (1986, p. 279). 
mente distintas, tendo em vista as dúvidas relativas aos ramos $\mathrm{A} / \mathrm{B}$ e $\mathrm{E} / \mathrm{F}$ já expostas acima. Na primeira hipótese, que julgamos ser a mais provável, $\mathrm{B}$ e $\mathrm{F}$ figuram como cópias de A e E, respectivamente. Dentre as diversas possíveis contaminações de manuscritos pertencentes a ramos distintos, representamos apenas a provável ligação entre $\mathrm{C}$ e o ramo $\mathrm{A} / \mathrm{B}$ e as coincidências entre $\mathrm{G}$ e o ramo $\mathrm{E} / \mathrm{F}$, por serem as que possuem indícios mais relevantes no texto. ${ }^{41}$

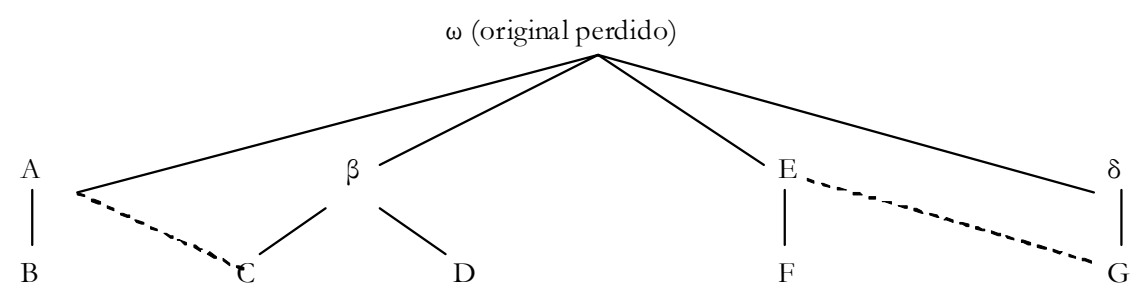

A segunda hipótese para o estema prevê um número maior de códices intermediários desaparecidos, que ocupariam a posição de subarquétipos dos $\operatorname{ramos} \mathrm{A} / \mathrm{B}$ e E/F:

$\mathrm{A}$

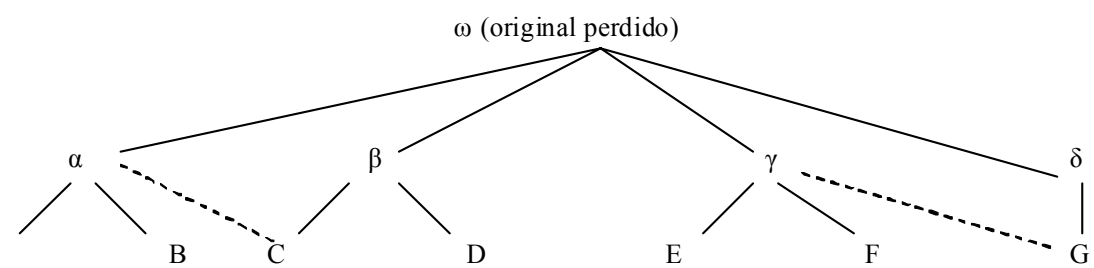

Os resultados da colação parecem confirmados ainda pela variação dos títulos que a obra recebe nos diversos manuscritos, como é possível verificar pela descrição dos códices apresentada acima. Com efeito, as cópias do ramo A/B apresentam exatamente o mesmo título; o mesmo ocorre com os códices E e F, que também julgamos estreitamente aparentados. Já entre os códices $C$ e $\mathrm{D}$, cujas relações não são significativas a ponto de autorizar descrevê-los como um novo ramo da tradição manuscrita, não há coincidência de títulos. Quanto ao título atribuído ao texto pelo amanuense de $\mathrm{G}$ nota-se que ele é

${ }^{41}$ Ver a propósito a tabela 3.6 (relações entre C e A/B) e o ex. 2 da tabela 4.8 (relação entre $\mathrm{G}$ e E/F). Outro provável caso de contaminação, não representado no estema por estar baseado em indícios menos seguros, seria o possível contato entre G e os códices C e D (cf. tabela 3.5, exemplos 1 e 4), entre outros. 
muito semelhante ao do códice $\mathrm{D}$, embora a possível proximidade entre $\mathrm{D}$ e G sugerida pelos títulos dos códices não tenha sido confirmada pelos achados da colação.

Apesar das dúvidas expostas, o exame da tradição manuscrita da Crônica de D. Duardos I permitiu concluir pela superioridade dos códices A e C em comparação com os demais testemunhos conhecidos do texto. Uma futura edição dessa obra ainda inédita deve adotar como ponto de partida, portanto, a lição um desses dois códices.

\section{Bibliografia}

AZEVEDO FILHO, L. A. (1987) Iniciação em crítica textual. Rio de Janeiro: Presença/São Paulo: Edusp.

FERNANDES, R. C. G. (2006) Crônica de D. Duardos (Primeira Parte), cód. BNL 12904: edição e estudo. Universidade de São Paulo.

FIGUEIREDO, F. (1930) História da literatura clássica. 2. ed. Lisboa: Clássica.

FINAZZI-AGRÒ, E. (1978) A novelística portuguesa do século XVI. Trad. Carlos Moura. Lisboa: Instituto de Cultura Portuguesa.

LANCIANI, G. (1986) Textos portugueses dos séculos XVI a XVIII. Problemas ecdóticos. Separata de Critique textuelle portugaise: Actes du colloque. Paris: Fondation Calouste Gulbenkian. p. $279-285$.

MOISÉS, M. (1957) A novela de cavalaria portuguesa: achega bibliográfica. Revista de História, 29 , p. 47-52.

PAIVA, D. F. (1988) História da língua portuguesa. II. Século XV e meados do século XVI. São Paulo: Ática.

PALMA-FERREIRA, J. (1983) Prefácio. In: Crónica do Imperador Maximiliano, Cód. 490, Col. Pombalina da Biblioteca Nacional. Lisboa: Imprensa Nacional / Casa da Moeda.

PICCHIO, L. S. (1979) Proto-história dos Palmeirins: a corte de Contantinopla do Cligès ao Palmerín de Olivia. In: A lição do texto: filologia e literatura. Lisboa: Edições 70.

PURSER, W. E. (1904) Palmerin of England. Some remarks on this romance and on the controversy concerning its authorship. Dublin: Brown and Nolan.

RAMOS COELHO. (1903) O primeiro Marquês de Niza. In: Archivo Histórico Português, 1, separata.

SILVA, I. F. (1973) Diccionario bibliographico portuguez: estudos de Innocencio Francisco da Silva applicaveis a Portugal e ao Brasil. Lisboa: Imprensa Nacional/Casa da Moeda.

SOUSA, A. C. (1946-1955) História genealógica da Casa Real Portuguesa. Nova ed. revista por M. Lopes de Almeida e César Pegado. Coimbra: Atlântida.

SPAGGIARI, B.; PERUGI, M. (2004) Fundamentos da crítica textual. Rio de Janeiro: Lucerna. SPINA, S. (1977) Introdução à edótica. São Paulo: Cultrix/Edusp.

VARGAS DÍAZ-TOLEDO, A. (2004) Leomundo de Grecia: hallazgo de un nuevo livro de caballerías portugués. Vozy letra, 15 (2), p. 3-32. 
(2006) Apéndices. In: MORAIS, F. de Palmerín de Ingalaterra (Libro I). Ed. de Aurelio Vargas Díaz-Toledo. Alcalá de Henares: Centro de Estudios Cervantinos.

ABSTRACT: Francisco de Morais' Palmeirim de Inglaterra is the most famous Portuguese romance of chivalry. Beyond the known edited sequence of this work, there is another one that remains unpublished: it is the book we call Crônica de D. Duardos, probably written in the late sixteenth century, which has been preserved only in manuscript copies. The purpose of this paper is to examine the manuscript tradition of the first part od this Crônica in order to prepare the edition of the text.

KEYWORDS: Romances of chivalry; manuscript tradition; Portuguese Renaissance. 